\title{
Prescribing Hemodialysis or Hemodiafiltration: When One Size Does Not Fit All the Proposal of a Personalized Approach Based on Comorbidity and Nutritional Status
}

\author{
Giorgina Barbara Piccoli ${ }^{1,2, *}$, , Louise Nielsen ${ }^{1}$, Lurilyn Gendrot ${ }^{1}$, Antioco Fois ${ }^{1}$, \\ Emanuela Cataldo ${ }^{1,3}$ and Gianfranca Cabiddu ${ }^{4}(\mathbb{B}$ \\ 1 Néphrologie Centre Hospitalier Le Mans, Avenue Roubillard 196, 72000 Le Mans, France; \\ lnielsen@ch-lemans.fr (L.N.); lgendrot@ch-lemans.fr (L.G.); afois@ch-lemans.fr (A.F.); \\ emanuela.cataldo@gmail.com (E.C.) \\ 2 Dipartimento di Scienze Cliniche e Biologiche, University of Torino, Ospedale san Luigi, Regione Gonzole, \\ 10100 Torino, Italy \\ 3 Nefrologia, Università Aldo Moro, Piazza Umberto I, 70121 Bari, Italy \\ 4 Nefrologia Ospedale Brotzu, Piazzale Alessandro Ricchi, 1, 09134 Cagliari, Italy; gianfranca.cabiddu@tin.it \\ * Correspondence: gbpiccoli@yahoo.it; Tel.: +33-669-733-371
}

Received: 8 August 2018; Accepted: 26 September 2018; Published: 8 October 2018

\begin{abstract}
There is no simple way to prescribe hemodialysis. Changes in the dialysis population, improvements in dialysis techniques, and different attitudes towards the initiation of dialysis have influenced treatment goals and, consequently, dialysis prescription. However, in clinical practice prescription of dialysis still often follows a "one size fits all" rule, and there is no agreed distinction between treatment goals for the younger, lower-risk population, and for older, high comorbidity patients. In the younger dialysis population, efficiency is our main goal, as assessed by the demonstrated close relationship between depuration (tested by kinetic adequacy) and survival. In the ageing dialysis population, tolerance is probably a better objective: "good dialysis" should allow the patient to attain a stable metabolic balance with minimal dialysis-related morbidity. We would like therefore to open the discussion on a personalized approach to dialysis prescription, focused on efficiency in younger patients and on tolerance in older ones, based on life expectancy, comorbidity, residual kidney function, and nutritional status, with particular attention placed on elderly, high-comorbidity populations, such as the ones presently treated in most European centers. Prescription of dialysis includes reaching decisions on the following elements: dialysis modality (hemodialysis (HD) or hemodiafiltration (HDF)); type of membrane (permeability, surface); and the frequency and duration of sessions. Blood and dialysate flow, anticoagulation, and reinfusion (in HDF) are also briefly discussed. The approach described in this concept paper was developed considering the following items: nutritional markers and integrated scores (albumin, pre-albumin, cholesterol; body size, Body Mass Index (BMI), Malnutrition Inflammation Score (MIS), and Subjective Global Assessment (SGA)); life expectancy (age, comorbidity (Charlson Index), and dialysis vintage); kinetic goals $(\mathrm{Kt} / \mathrm{V}$, normalized protein catabolic rate (n-PCR), calcium phosphate, parathyroid hormone (PTH), beta-2 microglobulin); technical aspects including vascular access (fistula versus catheter, degree of functionality); residual kidney function and weight gain; and dialysis tolerance (intradialytic hypotension, post-dialysis fatigue, and subjective evaluation of the effect of dialysis on quality of life). In the era of personalized medicine, we hope the approach described in this concept paper, which requires validation but has the merit of providing innovation, may be a first step towards raising attention on this issue and will be of help in guiding dialysis choices that exploit the extraordinary potential of the present dialysis "menu".
\end{abstract}


Keywords: hemodialysis; hemodiafiltration; life expectancy; incremental dialysis; daily hemodialysis; personalization of treatment

\section{Diet and Hemodialysis Prescription: A Necessary Integration}

No treatment or schedule of dialysis is univocally recognized as superior, and, partly as a consequence, there continues to be no simple method of prescription [1].

Oversimplifying, we could say that dialysis is a treatment employed to remove metabolic waste, via an intra- or extracorporeal process, from the blood of people whose native kidneys are not able to perform this function [1-4].

Metabolic waste may be of endogenous (metabolic) or exogenous (food intake) origin, but it is food intake that ultimately regulates the patient's anabolic and catabolic balance and also indirectly determines the level of uremic toxins, from the "simplest ones" such as urea or phosphate, to the complex, and less known "middle-molecules", such as beta-2 microglobulin, and to some extent, parathyroid hormone (PTH) [5-8]. While there is no clear definition of the term "uremic toxins", we will use it to identify substances present in the sera of uremic patients, with a specific detrimental effect in these subjects. According to a definition from a review by Glassock "A connection between the toxic substance and one or more of the patho-biological or clinical features of the uremic syndrome must be firmly demonstrated". In this broad definition, therefore, "physiological" molecules" such as phosphate or potassium are also included [9].

Adequate dialysis can therefore be seen as the procedure that makes it possible to attain a stable, acceptable long-term metabolic balance in patients without sufficient kidney function. Nutritional status, which is one of the most important survival markers in dialysis patients, is a key element in the global metabolic balance [10-12]. Attention to nutritional markers has progressive shifted from the reduction of potentially dangerous toxins (including potassium and phosphate), to an increase in vital nutrients and prevention of long-term problems [13-18] (Table 1).

Tailoring hemodialysis requires consideration of several, sometimes conflicting aspects. Depuration has to be efficient, but highly efficient depuration may remove useful nutrients. Dialysis has to be long enough to allow for depuration of compartmentalized substances and middle molecules, but dialysis tolerance is better with shorter sessions, or with "softer" treatments. Poor dialysis tolerance is associated with poor prognosis and quality of life, particularly in elderly patients. The idea of tailored dialysis may thus be resumed in focusing on highly efficient depuration in younger patients with good nutritional status, and on high tolerance in elderly patients, for whom life expectancy is short enough not to tailor dialysis based on avoidance of long-term problems.

In a context in which no available evidence clearly supports the choice of dialysis mode (hemodialysis versus hemodiafiltration, pre- versus post-dilution, longer versus shorter durations, incremental versus standardized dialysis), dialysis prescription still relies more on personal experiences and shared views [1-4].

Concept papers are papers which outline personal views and personal indications, based on a subjective reading of contrasting evidence, eventually guiding treatment strategies. Along this line, this paper resumes and offers to discussion an approach to dialysis prescription based upon integration between dialysis efficiency, markers of nutritional status and comorbidity. This approach is non-validated; this limitation is however an invitation to participate to discussion on the controversial issues of nutrition markers and dialysis policy. 
Table 1. "Magic numbers" employed in nutritional evaluation and dialysis prescriptions and their limits: some laboratory tests.

\begin{tabular}{|c|c|c|c|}
\hline Item & Magic numbers & Pros & Cons \\
\hline Albumin & $\begin{array}{l}\text { Normal } \geq 35 \mathrm{~g} / \mathrm{L} \text { to } \geq 40 \mathrm{~g} / \mathrm{L}, \\
\text { may differ according to } \\
\text { European or U.S. standards. }\end{array}$ & $\begin{array}{l}\text { Simple, readily available, } \\
\text { low cost, validated. }\end{array}$ & $\begin{array}{l}\text { Depends on hydration, sensitivity to losses } \\
\text { (especially in HDF or HD with } \\
\text { high-permeability membranes). } \\
\text { Validated in HD with thrice-weekly schedules. }\end{array}$ \\
\hline Pre-albumin & $\begin{array}{l}\text { Normal (depending on } \\
\text { laboratory); in general } \\
0.18-0.35 \mathrm{~g} / \mathrm{L} \text {. }\end{array}$ & $\begin{array}{l}\text { Influences the evaluation } \\
\text { of albumin levels. }\end{array}$ & $\begin{array}{l}\text { Relatively expensive, but not fully validated, } \\
\text { high variability. Little information for } \\
\text { elderly patients. }\end{array}$ \\
\hline $\mathrm{Kt} / \mathrm{V}$ & $\begin{array}{l}\text { Threshold for adequate } \\
\text { dialysis depends on the } \\
\text { formula chosen; adequate } \\
\text { dialysis is usually defined as } \\
\text { a level }>1.2-1.4 \text { in } \\
\text { thrice-weekly dialysis. }\end{array}$ & $\begin{array}{l}\text { Simple, readily available, } \\
\text { validated, low cost. }\end{array}$ & $\begin{array}{l}\text { Depends on formula, day of the week (first vs. } \\
\text { midweek dialysis), baseline urea level; post-dialysis } \\
\text { sample may be affected by urea rebound; may be } \\
\text { higher in malnourished patients (low volumes). } \\
\text { No fully validated formula for less and more } \\
\text { frequent dialysis. }\end{array}$ \\
\hline
\end{tabular}

$\mathrm{Kt} / \mathrm{V}$ : mathematical formula relating urea level before and after dialysis. n-PCR: normalized protein catabolic rate; HDF: hemodiafiltration; HD: hemodialysis.

\section{Tolerance beyond Depuration}

The dialysis population has deeply changed in the last decades, with an impressive increase in the number of elderly patients and patients with high numbers of comorbidities. Even if the overall number of young patients has not universally decreased kidney transplantation, due to great advances in the field, is now the best mode of renal replacement therapy in this population.

As a result, the approach to dialysis prescription, which tends towards personalization in several settings, needs to be adapted to various categories of patients that are distinct in terms of comorbidity and life expectancy.

Attaining efficient depuration, controlled by the classic kinetic markers, may not be sufficient in all patients, and may not be the priority in the present elderly and high-comorbidity dialysis population [19-23]. Prescription of all treatments, including dialysis, should first of all comply with the imperative "do no harm" [24-26]. The high mortality on initiation of dialysis, recently termed "dialysis shock" and the lack of advantages (and possible disadvantages) of early versus late dialysis initiation, together with the contrasting results of dialysis or supportive treatment in the elderly, indicate that dialysis saves lives, but not without cost [27-33].

In this regard, the "efficiency goal", stating that kinetic adequacy is the essential requisite for "good dialysis", is pertinent to younger patients, but is progressively replaced by a "tolerance goal" in the elderly, where "good dialysis" should have minimal side effects [34-36].

This paradigm shift has also led to renewed interest in "late" and, whenever possible, incremental dialysis initiation, in which, as occurs in peritoneal dialysis, hemodialysis is prescribed with a progressive increase in the number and duration of sessions to try to minimize "dialysis shock" and preserve residual renal function [37-42].

Thus, "intent-to-defer" has replaced "the earlier the better" policy of dialysis initiation, and the consideration of "too much of a good thing" has convinced many physicians that dialysis efficiency should be mitigated, at least in fragile populations [20,43]. Once more, nutritional issues are central to this discussion, since malnutrition is the main marker of frailty in dialysis patients [9-12,44-47].

At the same time, we have become aware that in elderly patients a policy merely aimed at highly efficient dialysis may not always be clinically sound, and, as stated recently in another concept paper 
on seminars in dialysis, "less may be better", privileging tolerance and tailored approaches in fragile patients [20].

Conversely, in the new millennium interest has increased in more frequent, high-efficiency dialysis; this option may be particularly advantageous for young patients with high metabolic demands (for example in the pregnant dialysis patient). The indications are however not sharp, and short, daily dialysis has been recognized also as a promising option for fragile patients [48-52].

In this changing panorama, the balance of hemodialysis prescription is shifting from standardization to personalization. Not surprisingly, different policies are followed in different settings, and similar treatments may be prescribed for different goals [53].

In an attempt to balance comprehensiveness and feasibility, we have tried to describe an approach to personalized dialysis, relying on some simple, readily available measures and markers (Tables 1 and 2). The algorithm shown in this paper, which is the outcome of extensive discussions at two in-hospital centers (one in Italy, the other in France), was specially conceived to meet the needs of fragile and elderly patients [53].

The schema is based on two options: HD (low flux) and HDF (pre- and post-dilution) (Figure 1).

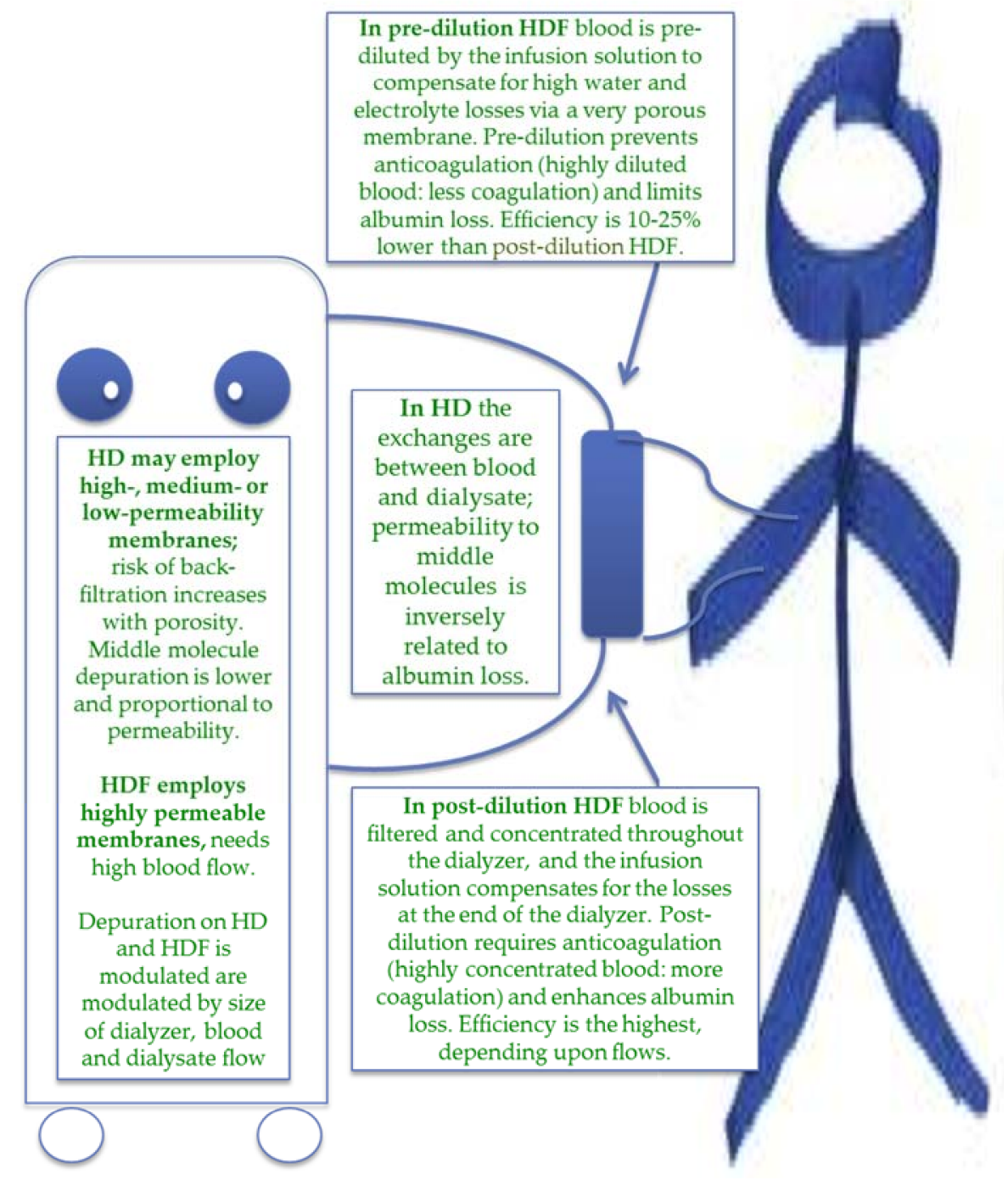

Figure 1. The main characteristics of hemodialysis (HD) and hemodiafiltration (HDF).

The following elements were considered and integrated: 
- Nutritional markers and integrated scores (albumin, pre-albumin, cholesterol; body size, Body mass index (BMI), Malnutrition Inflammation Score (MIS), Subjective Global Assessment (SGA)) [43,44,54-62];

- Life expectancy: age, comorbidity (Charlson Index), and dialysis vintage [60,63];

- Kinetic goals (Kt/V; n-PCR; calcium phosphate and PTH control; beta-2 microglobulin levels) [16,19-22];

- Technical aspects: vascular access (fistula versus catheter, degree of functionality, problems found) [64,65];

- Residual kidney function, weight gain [66-68];

- Dialysis tolerance (intradialysis hypotension, post-dialysis fatigue and subjective evaluation of the effect of dialysis on quality of life) [69].

The discussion on the prescription of dialysis includes:

- Dialysis frequency;

- Dialysis duration;

- Dialysis modality (hemodialysis (HD) or hemodiafiltration (HDF))

- Type of membrane (permeability; surface);

- Blood and dialysate flow (in HDF: pre- or post-dilutional modality);

- anticoagulation.

All these items will be discussed in a general, clinical manner, following clinical logic and guidance rather than kinetic modeling (Table 2).

Table 2. "Magic number" definitions and limits: hemodialysis (HD) and hemodiafiltration (HDF) prescriptions.

\begin{tabular}{|c|c|c|c|}
\hline Item & Number Definition & Advantages of the Definition & $\begin{array}{l}\text { Disadvantages/Limits } \\
\text { of Standardization }\end{array}$ \\
\hline Permeability & $\begin{array}{l}\text { Usually defined as high, } \\
\text { medium, or low with respect to } \\
\text { middle-molecule depuration; } \\
\text { different cut-points available, } \\
\text { no fully agreed definition. }\end{array}$ & $\begin{array}{l}\text { Clear and easy definition; } \\
\text { all types of membranes can be } \\
\text { used in HD, and only } \\
\text { high-permeability membranes } \\
\text { in HDF. Back-filtration in HD is } \\
\text { proportional to permeability. }\end{array}$ & $\begin{array}{l}\text { Differences are less sharp for } \\
\text { new membranes; research to } \\
\text { improve selectivity, differences } \\
\text { between membranes in the same } \\
\text { category may be relevant. }\end{array}$ \\
\hline Membrane size & $\begin{array}{l}\text { In square meters: usually related } \\
\text { to body surface } \\
\text { (lower/higher/equal). }\end{array}$ & $\begin{array}{l}\text { Clear and easy; several surfaces } \\
\text { usually available for each } \\
\text { membrane type. }\end{array}$ & $\begin{array}{l}\text { Membrane size is related to } \\
\text { membrane type } \\
\text { and anticoagulation; effect of } \\
\text { size on depuration depends on } \\
\text { membrane performance. }\end{array}$ \\
\hline Blood flow & $\begin{array}{l}\text { No fully agreed standard; } \\
\text { European reference } \\
300-350 \mathrm{~mL} / \mathrm{min} \text {; in other } \\
\text { settings target flow may be as } \\
\text { high as } 450 \mathrm{~mL} / \mathrm{min} \text {. }\end{array}$ & $\begin{array}{l}\text { Clear and easy definition; } \\
\text { good blood flow is also a marker } \\
\text { of correct functioning of the } \\
\text { vascular access. }\end{array}$ & $\begin{array}{l}\text { Target may vary according to } \\
\text { vascular access and type of } \\
\text { treatment (lower in } \\
\text { long-hour dialysis). } \\
\text { Highly dependent on } \\
\text { vascular access. }\end{array}$ \\
\hline Dialysate flow & $\begin{array}{l}\text { No fully agreed standard; } \\
\text { European reference } \\
500 \mathrm{~mL} / \mathrm{min} . \text {, may be as high } \\
\text { as } 800 \mathrm{~mL} / \mathrm{min} \text {. }\end{array}$ & $\begin{array}{l}\text { Clear and easy definition; } \\
\text { agreed international standard. }\end{array}$ & $\begin{array}{l}\text { Prescription can be adjusted } \\
\text { (higher in HDF, lower in some } \\
\text { types of daily dialysis). }\end{array}$ \\
\hline Reinfusion (HDF) & $\begin{array}{l}\text { No fully agreed standard; } \\
\text { European reference } 24 \mathrm{~L} / \text { session } \\
\text { on HDF. }\end{array}$ & $\begin{array}{l}\text { Clear relationship between } \\
\text { exchanges and } \\
\text { middle-molecule depuration. }\end{array}$ & $\begin{array}{l}\text { Standards are different across } \\
\text { the world; pre-/post-dilution } \\
\text { protocols are different; loss of } \\
\text { albumin may increase with } \\
\text { high exchanges. }\end{array}$ \\
\hline $\begin{array}{c}\text { Number of } \\
\text { dialysis sessions }\end{array}$ & $\begin{array}{l}\text { Thrice-weekly; incremental: } \\
1-2 \text { per week with } \\
\text { progressive increase; } \\
\text { intensive: } 4-7 \text { per week. "daily } \\
\text { dialysis" at least } 5 \text { per week. }\end{array}$ & Clear, simple, validated. & $\begin{array}{l}\text { All frequencies that differ from } \\
\text { thrice-weekly are less validated, } \\
\text { protocols are highly } \\
\text { center-dependent. }\end{array}$ \\
\hline Dialysis duration & $\begin{array}{l}\text { Standard: } 4 \mathrm{~h} \text { thrice-weekly; } \\
\text { shorter in "short" daily dialysis; } \\
\text { various combinations of } 2-8 \mathrm{~h} \\
\text { and } 1-7 \text { sessions. }\end{array}$ & Clear, simple, validated. & $\begin{array}{l}\text { All durations that differ from } 4 \mathrm{~h} \\
\text { are less validated, protocols are } \\
\text { highly center-dependent. }\end{array}$ \\
\hline
\end{tabular}




\section{Arbitrary (or Unproven) Assumptions}

The algorithm proposed is based on some arbitrary, or unproven assumptions:

- Albumin is the most relevant prognostic marker in both HDF and HD [70-73];

- Albumin loss is non-selective, and low serum albumin levels have to be avoided [74-78] (i.e., "toxic albumin", is not selectively lost; toxic albumin is albumin-linked to uremic toxins, for which loss should be promoted according to some authors [73,74];

- Different dialyzers in the same category are equivalent (high-, medium- or low-flux) in terms of performance and albumin leakage (while this is not entirely true, a detailed discussion is beyond the scope of this review);

- Loss of albumin is higher in the first minutes of HDF, supporting the choice of low-permeability membranes in the case of more frequent dialysis [74];

- Loss of albumin is also a marker of loss of other potentially useful nutrients, including vitamins; such a loss may contribute to malnutrition;

- Adsorption by dialysis membranes is not a relevant element in the removal of uremic toxins; if present, it is similar in similar categories of dialyzers [78].

Conversely, in this discussion we have not discussed pre-analytical and analytical errors, which may introduce further variability in the elements on which a decision is based. Furthermore, we have not considered the differences in the cost of treatments: in the past HD was often chosen in settings where the cost of HDF was significantly higher, but since the differences are leveling off in many European countries, we have considered the two treatments as equivalent.

\section{Nutritional Markers and Integrated Scores}

There are many validated nutritional markers, all characterized by serving also as mortality markers. We chose the following ones because of their simplicity, ready availability, and relatively low cost: albumin, cholesterol; body size, BMI, Malnutrition Inflammation Score (MIS), and Subjective Global Assessment (SGA) [44-46,61,62]. The only exception is pre-albumin, which we consider in our discussion, in spite of the fact that it has not yet been systematically integrated into the routine testing of dialysis patients (Figure 2) [79].

SGA and MIS are somehow complementary: the first is more sensitive to changes in nutritional status, while the latter combines nutritional and inflammation markers, giving us a potential tool to discriminate between malnutrition induced by an insufficient diet or by inadequate dialysis, which is potentially modifiable, and malnutrition resulting from inflammation and atherosclerosis, which is less likely to respond to dialysis intensification or nutritional optimization [80-85]. 


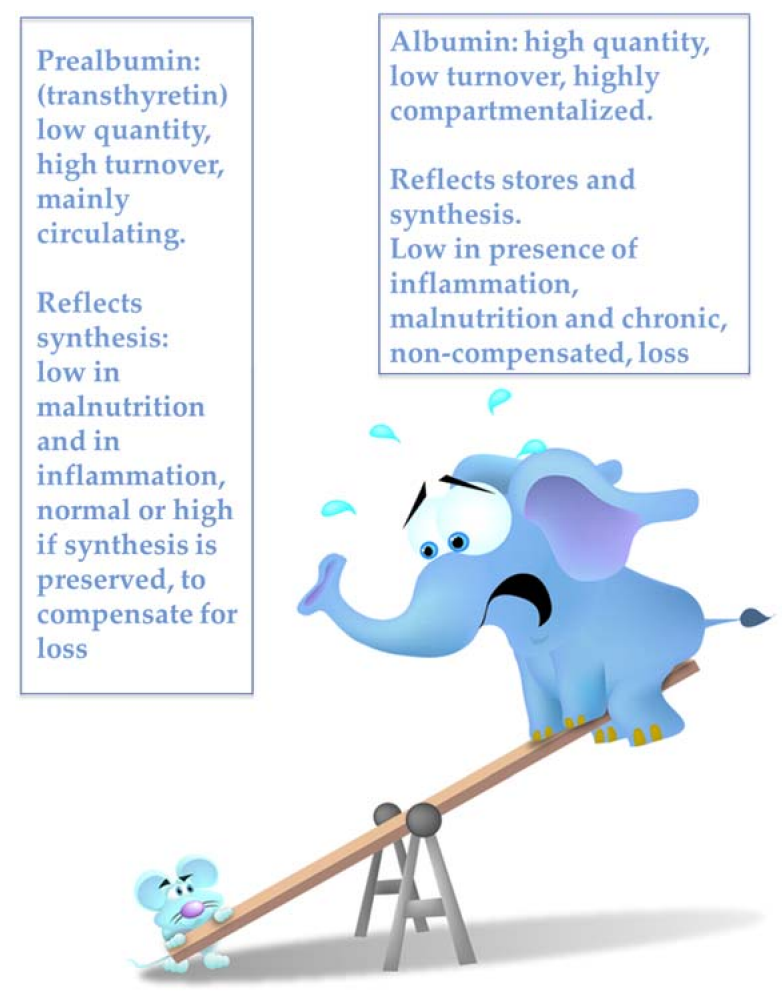

Figure 2. The albumin-prealbumin issue.

\section{Patient Categorization}

Comorbidity and nutritional status describe different categories of patients: "good" (all nutritional markers are concordant and well preserved; comorbidity is low); "bad" (all nutritional markers are altered; comorbidity is high); and "discrepant" (some nutritional markers are normal, while others are impaired, and the comorbid burden is variable).

As previously mentioned, we considered albumin level as the leading nutritional marker, given its close relationship with survival, its availability, and its low cost [86-91].

The assessment of the nutritional status is further combined with comorbidity, type of vascular access and treatment tolerance, to be summarized in decisional algorithms, as will be further discussed.

\section{Good Nutritional Status, Good Clinical Condition, Low MIS}

The presence of good nutritional status, good general condition, low comorbidity, and low malnutrition inflammation score is the portrait of "the ideal dialysis patient", a portrait less and less present in our dialysis wards due to the ageing of the population and to the selection of the fittest patients for transplantation, and even more so where the choice of preemptive transplantation is available (Figure 3).

Since this profile is associated with the longest survival, dialysis prescription should be aimed at attaining high efficiency targets. In younger patients in particular HDF may be preferable, provided ultrapure water is available given its protective effect against the risk of developing dialysis-related beta-2 amyloidosis, which is not only a severe disease, but may also be the marker of the negative effects of long-term exposure to uremia [92-98].

While the different membranes have different albumin losses, the entity of leakage, adhesion and overall loss of albumin is only partially acknowledged; albumin may indeed be seen as a marker of loss of potentially important nutrients and will be discussed as such in this paper. 


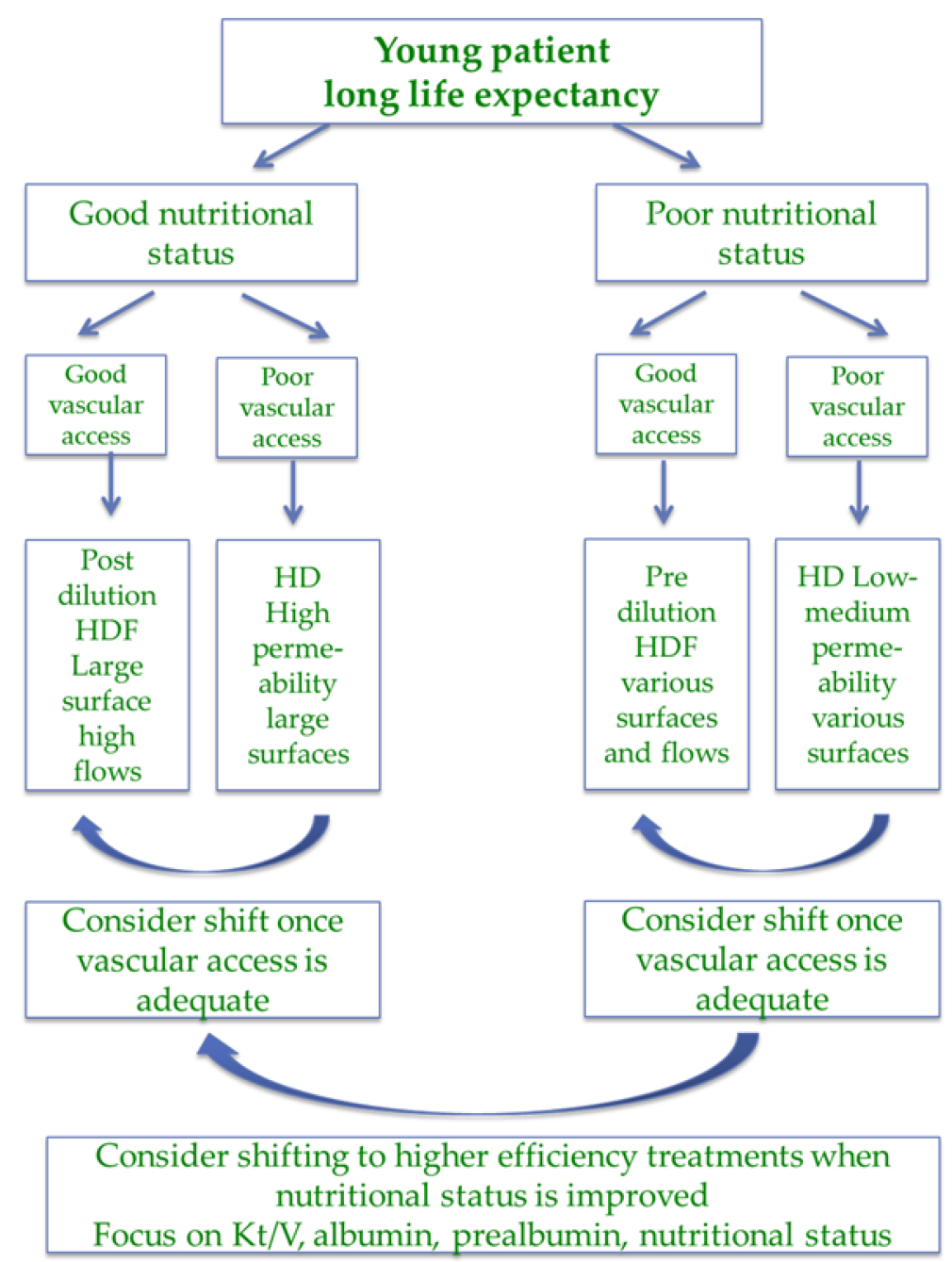

Figure 3. Choice of dialysis (hemodialysis (HD) or hemodiafiltration (HDF)) in the "ideal patient".

In well-nourished patients, albumin losses through high-permeability dialysis membranes are likely to be compensated by adequate production, and high-efficiency dialysis allows them to follow a less restricted diet with higher protein intake $[98,99]$. While some groups hold that high-permeability dialyzers allow us to obtain similar efficiency in HD and HDF, based on the current evidence, we believe that HDF is preferable, at least where cost is only marginally higher. This is particularly so in cases where significant weight loss is not an issue, as HDF prevents back-filtration, which may offset the advantages of high depuration by eliciting inflammation [100,101].

Since dialysis-related amyloidosis is the prototype of long-term treatment-related comorbidity, low beta-2 microglobulin levels represent a good long-term treatment marker. Japanese and French studies have demonstrated the superiority of HDF in retarding the clinical onset of amyloidosis. We consider that an investment in high-flux HDF is also worthwhile when a patient is likely to receive a transplant, even without a long wait, given the long life expectancy and considering the non-reversibility of amyloid changes after transplantation [92-98].

Policies may differ worldwide. For example, post-dilution, high-flow HDF with high-surface, high-permeability dialyzers is the main type of HDF employed in France, while the Japanese approach is milder and mainly employs pre-dilution $\operatorname{HDF}[14,20,21]$.

Following a nutrition-based approach, it is conceivable that the more aggressive strategy should be reserved to patients with good nutritional status; a compromise between removal of middle molecules and control of albumin loss may lead to pre-dilution schedules. 
The advantages of high-efficiency HDF are less evident in older patients with shorter life expectancy, in which HD may be a reasonable choice, in particular when residual renal function is present; these patients may fail compensating for albumin loss, and shorter life expectancy makes it unlikely that they will develop dialysis-related amyloidosis, which generally takes at least ten years to become clinically evident [100-105].

Steps to reduce albumin loss, at all ages, may also need to be taken in case of acute inflammatory events [104-108].

\section{Poor Nutritional Status, Poor Clinical Condition, High MIS}

In countries where transplantation is highly developed, the clinical profile of patients on dialysis, in particular in the hospital, is much less favorable, and the combination of old age, high comorbidity and poor nutritional status is, in general, the rule. Patients in this subset belong to three main categories: individuals with a short life expectancy and with impaired nutritional status, patients with long dialysis follow-up, and patients with acute, potentially reversible diseases, including under-dialysis or "unhealthy" dialysis initiation [41-44,109-111] (Figures 4 and 5).

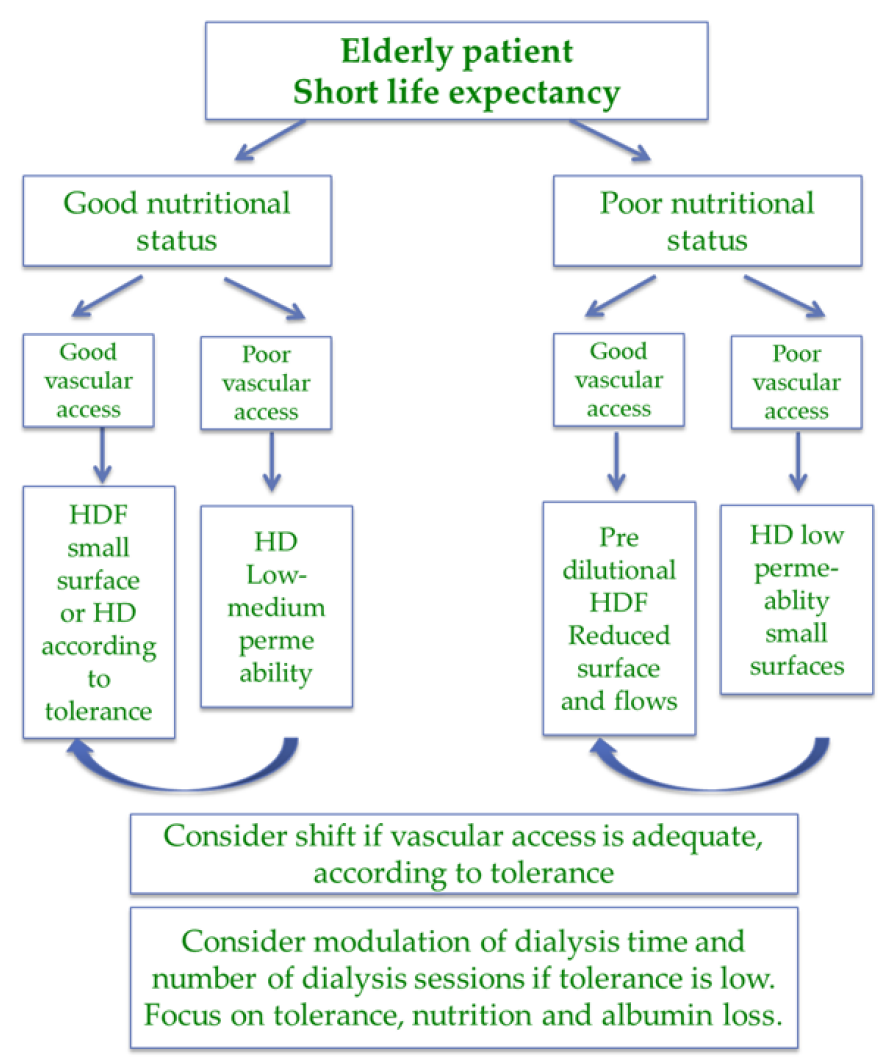

Figure 4. Choice of dialysis (hemodialysis (HD) or hemodiafiltration (HDF)) in the elderly fragile patient.

In the first group of frail patients, with limited potential for reversing comorbidity, treatment should probably be targeted to optimal tolerance, with attention to nutrient losses [104-108].

Several policies may be pursued for high-tolerance dialysis. On a thrice-weekly schedule, HD may be less well tolerated than HDF; however, HD with low-permeability membranes has the advantage of limiting albumin and nutrient loss, and is the method of choice in short, daily dialysis, a treatment with superior tolerance [109-119].

Pre-dilution or mixed dilution HDF (with the potential advantage of reducing or avoiding the need for anticoagulants), low-volume HDF and eventually low-flux dialysis (dialysate 300-500 mL, blood $200-250 \mathrm{~mL} / \mathrm{min}$ ), as performed in different combination in long nightly dialysis or in short 
daily dialysis, should also be considered as ways to combine tolerance and limitation of nutrient loss [50-52,120-122]. Dialyzers with comparatively smaller surfaces (less than the body surface) are preferred in malnourished patients who do not have the need for high convective volumes.

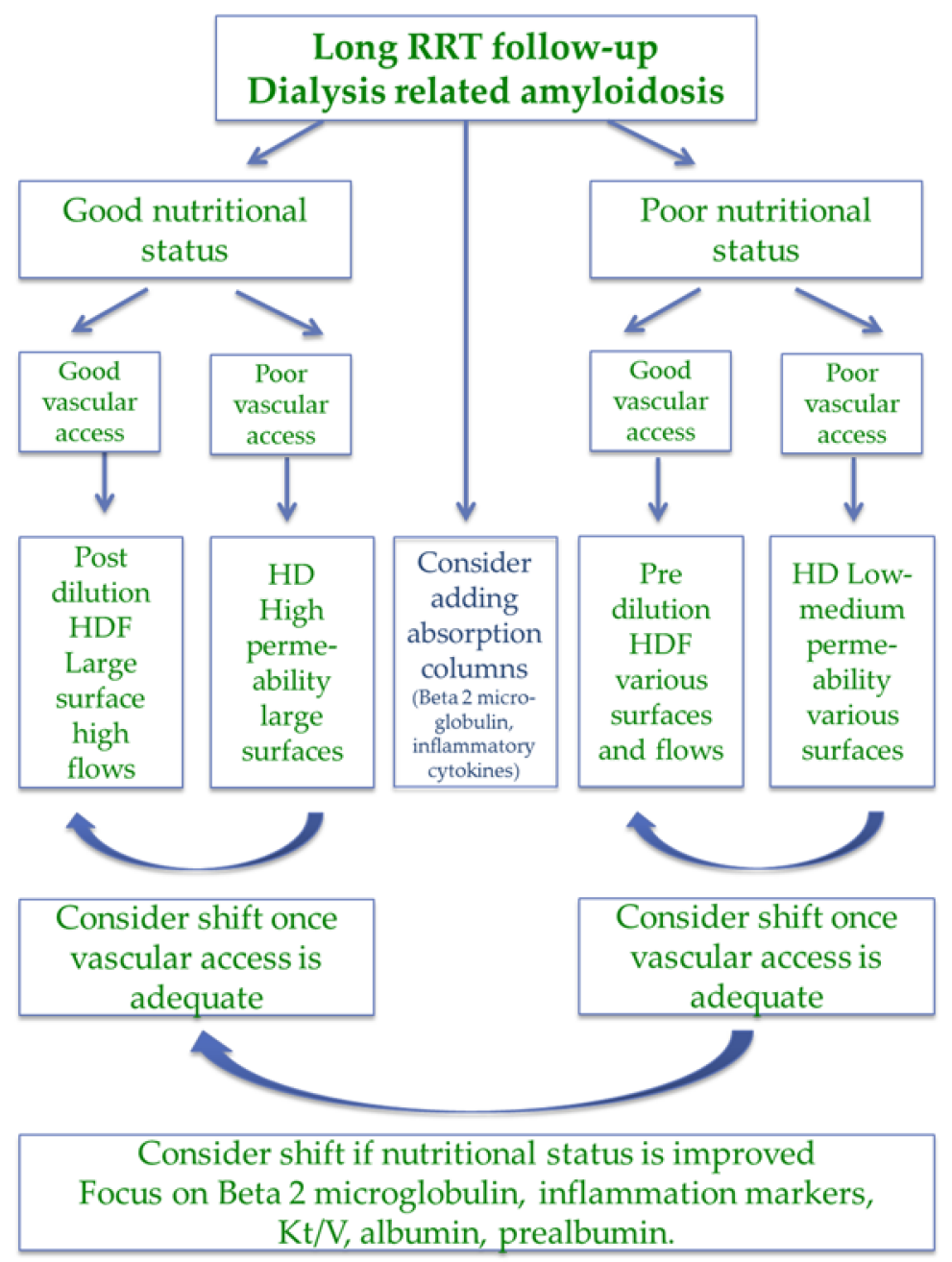

Figure 5. Choice of dialysis (hemodialysis (HD) or hemodiafiltration (HDF)) in the patients with long-term follow-up on renal replacement therapy (RRT).

At dialysis start, incremental policies allow us to test for tolerance, starting with once- or twice-weekly sessions of 2-3 h, and progressively increasing frequency or duration according to need for increasing depuration or ultrafiltration and to tolerance [37-41,123-129] (Figure 6).

Since tolerance is strictly linked to dialysis duration, we consider that a reasonable policy may be that of starting with relatively short dialysis sessions (2-3 h), progressively increasing the number, up to three sessions, and deciding, when needed and based upon tolerance, if shifting to the classic $12 \mathrm{~h}$ per week divided into three sessions of $4 \mathrm{~h}$ or into four sessions of $3 \mathrm{~h}$. A similar policy of small session may be proposed in patients already on dialysis but with poor tolerance, severe hypertension, or who need intensive metabolic correction (Figure 6). 


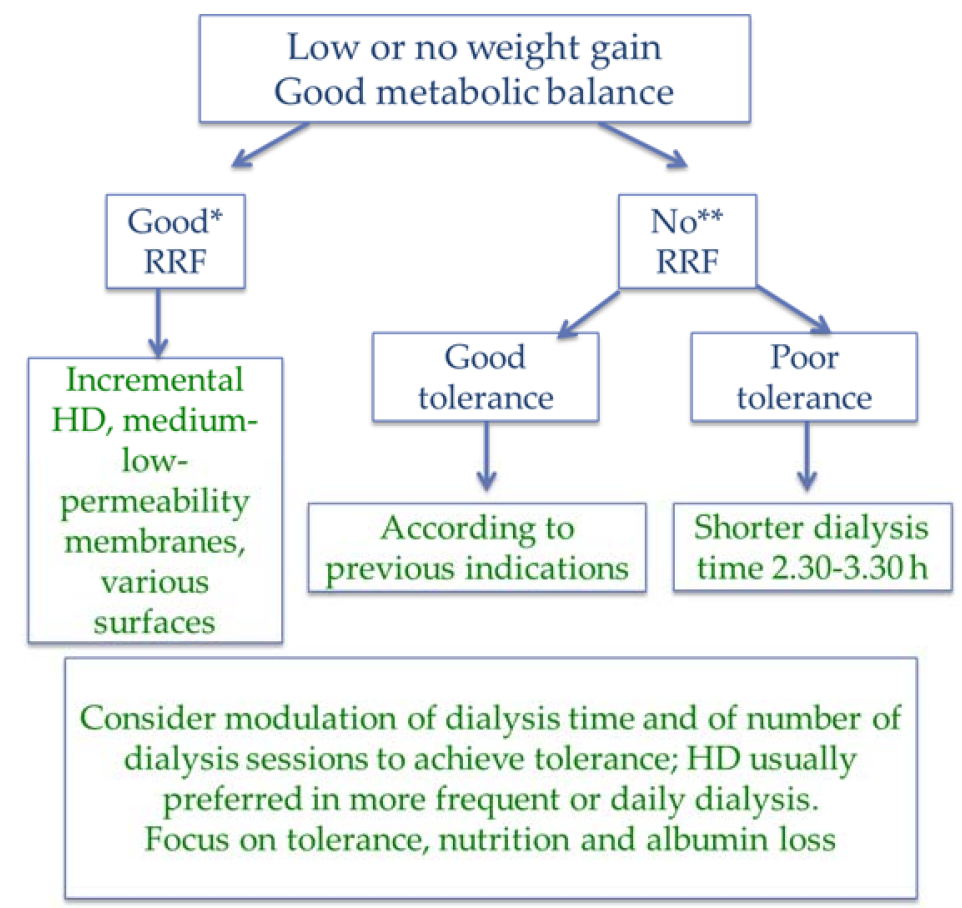

Figure 6. Short and incremental dialysis: "soft is best". Good RRF $\left.{ }^{*}\right)$ : urine output arbitrarily defined as at least $750 \mathrm{~mL} /$ day, according to body surface. Survival advantage is reported for residual diuresis $>250 \mathrm{~mL} /$ day [130-132]. No significant RRF $\left.{ }^{* *}\right)$ : arbitrarily defined as urine output less than $500 \mathrm{~mL}$. RRF measure: creatinine clearance or average urea and creatinine clearance (clearance $6-10 \mathrm{~mL} / \mathrm{min}$ : 1 session; 3-6 mL/min: 2 sessions, modulated upon weight gain, BUN, Ca-Ph-PTH, acidosis, nutritional status, tolerance, life expectancy).

The use of high-permeability membranes in HD is currently the choice in many settings, although the risk of back-filtration is far from negligible, in particular when weight loss is minimal. While it is true that using ultrapure water should offset the risks involved, the advantages, if any, of are not clear [133].

In patients starting dialysis with a potentially reversible impairment of nutritional status, we usually prefer to start with HD with low-permeability membranes, and to shift them to high-efficacy HDF to increase middle-molecule depuration as soon as the clinical situation has stabilized and nutritional markers (first of all prealbumin) start ameliorating.

The new generation of dialyzers with selective permeability to middle molecules may help solve this dichotomy, if they maintain the promised long-term benefits $[130,134,135]$.

\section{Discrepant Measures of Nutritional Status, Clinical Condition, MIS}

Dialysis patients are not easily described by a black-and-white, contrasted picture, and intermediate pictures are often present; the most common one, at least in our settings, is the combination of obesity, high comorbidity and high MIS index, with or without low albumin levels.

Mortality and obesity are linked in a paradoxical relationship [131,132,136-145]. A high BMI is not necessarily a sign of good nutrition, and obese sarcopenia may mask significant protein malnutrition $[139,140,144]$. Impedance analysis can help us identify sarcopenic obesity, but data have to be considered with caution, since impedance is less precise in obese patients [140].

It may be difficult for patients with a high BMI to reach the efficiency target, even if adjusted Kt/V is followed [143,144]; in cases in which the attainment of metabolic targets is difficult, more frequent dialysis should be considered, even if formal demonstration of an advantage is lacking.

Among dialysis patients, those with a low BMI usually have a poor nutritional status, even if some exceptions may occur patients who are active or practice a sport. Conversely, an extremely low 
BMI is invariably a sign of poor nutrition, and a low BMI is therefore considered to be one of the general indexes of malnutrition [146-148].

Albumin is a "leading biomarker", integrated into prognostic scores, including MIS and the dialysis-adapted Charlson Index [146-149]. Discrepant patterns are sometimes found, however. The most common one observed in our practice is the association between low albumin levels, normal or high BMI, normal cholesterol, and normal pre-albumin levels [53].

Pre-albumin (or transthyretin) is a reliable short-term marker of protein synthesis, sensitive, as albumin is, to inflammation, acute diseases and critically reduced food intake [146]. Normal pre-albumin associated with low albumin levels suggests an anabolic phase or chronic albumin losses (including intradialytic loss and ascites). Several other makers of protein turnover have been proposed, including complement proteins, immunoglobulin levels, uric acid, or more recently Klotho, fibroblast growth factor 23 (FGF23), and osteoprotegerin (OPG), but their use has not yet been codified in the clinical practice [150-157].

\section{Vascular Access and Anticoagulation}

Well-functioning vascular access is of obvious importance in dialysis and is a requisite for HDF [158-163]. While the imperative "fistula first" is still valid for patients with a longer life expectancy, poor vascular patrimonies, severe cardiac disease, chronic hypotension, hypercoagulability, and the failure of previous artero-venous (AV) fistulae or grafts increase the need for permanent catheters. In older patients, a distal, native AV fistula may not be feasible. Algorithms based on age and comorbidity now often privilege permanent catheters in elderly patients with a short life expectancy and suggest considering prosthetic or proximal fistula as a first option in patients with intermediate characteristics [164-168].

Even if malfunction is not a prerogative of indwelling catheters, low flows are common, in particular if these catheters are the rescue choice in patients with previous failures of an $\mathrm{AV}$ fistula or graft. In this context, HD may be a more reasonable choice, in the presence of lower blood flow (Figures 2-4).

The need for anticoagulation is an important issue: besides cases with anti-heparin antibodies or hemorrhagic disorders, in which heparin has to be avoided, avoiding or minimizing heparin reduces hemorrhagic risks, in particular for elderly patients treated with antiplatelet agents and anticoagulants [169-171]. Fistula malfunction increases the risk of intradialytic coagulation, in particular in post-dilution HDF. Predilution HDF is a very good choice in patients with a well-functioning AV fistula, while HD is more manageable at low blood flows, but heparin administration may need to be increased; shorter and more frequent HD can be performed without anticoagulation. Heparin-coated membranes should be considered in selected cases [172,173].

\section{Dialysis Initiation and Residual Renal Function}

The preservation of residual renal function correlates positively with survival. In this context, incremental dialysis combines the advantages of better preservation of the kidney function with lower dialysis-related morbidity, and lower costs [174-177].

The high mortality seen during the initial period of dialysis and the lack of advantages associated with "early" dialysis initiation suggest that a cautious increase in treatment time and frequency could be advantageous; the approach is not agreed and one large retrospective study suggests that dialysis in facilities that practice a more aggressive dialysis start (first session) is associated with better survival [178] (Figure 6).

While HDF has been reported to better preserve residual renal function, the evidence is scant, and the most common approaches are based on short HD, progressively increasing in duration and/or frequency [37-42]. In fact, it has been found that post-dialysis fatigue and intradilalytic tolerance correlate with the duration of sessions [179].

The lack of agreed approaches and kinetic targets and the fact that there is no agreed way to assess residual clearances, make it difficult to assess the adequacy of incremental dialysis. Bearing this in 
mind, in prescribing an increase in dialysis frequency or duration in the context of incremental dialysis, we follow the same clinical criteria that induce us to start dialysis treatment, namely hypertension, weight gain, anemia, nutritional status, and calcium phosphate, PTH and acid-base balances.

Decisions may be difficult in patients with nephrotic syndrome, in which the advantages of offsetting proteinuria by vigorous dehydration, combined with Angiotensin converting enzyme inhibitors and/or angiotensin receptor blockers when necessary, have to be balanced against loss of renal function; no study, to the best of our knowledge, has specifically addressed this issue, and decisions should be made case per case.

Patients with failing kidney grafts also pose further challenging problems: signs of protein wasting are frequent, in particular in patients on long-term steroids; criteria for dialysis initiation are otherwise not different before transplantation and after graft failure [180-182]. The question of when and how to discontinue antirejection drugs still needs to be clarified: while the trend was to rapidly discontinue antirejection drugs as soon as dialysis was started, the trend is now to keep them at low doses at least in cases in which a further graft is possible. In these often fragile patients, increased susceptibility to infections and chronic inflammation (and possibly also chronic rejection) can counteract efforts to improve nutritional status, even in the presence of high dialysis efficiency.

Conversely, daily dialysis and highly efficient dialysis may offer interesting solutions to two opposite problems: low tolerance, overcome by shortening the sessions, and need for higher efficiency, by increasing time and frequency (Figure 7).

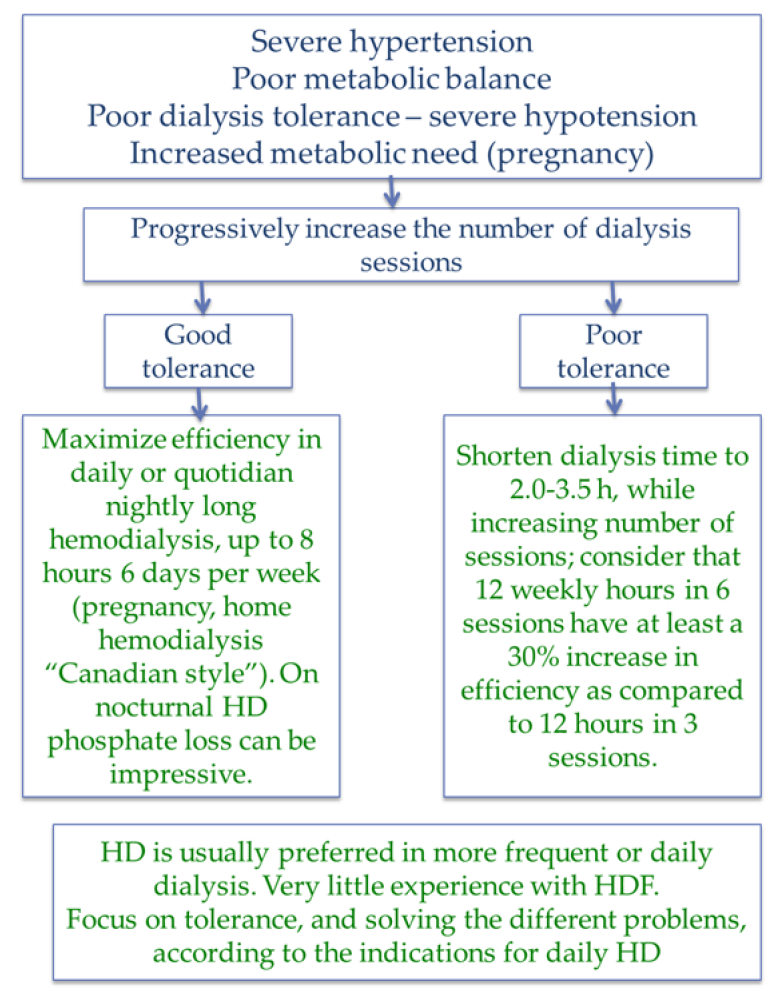

Figure 7. Daily and more efficient dialysis.

\section{What This Review Did Not Address}

This review was undertaken to serve as a basis for discussion on dialysis prescription, in particular for those cases escaping the classic "efficiency rules", namely elderly patients with high comorbidity. The decisional pathway was established employing common markers, most of them controlled in our monthly "dialysis profiles".

In our search for a simple approach, we did not consider many important points, including in-depth diagnosis of protein energy wasting, the psychological aspects of malnutrition and its link 
with depression. Furthermore, we did not include certain important elements in the decisional strategy, such as potassium and bicarbonate, fluid and sodium, blood pressure and brain natriuretic peptide (BNP). We have not dealt with nutritional interventions in dialysis patients, a complex issue beyond the scope of the present review, which focuses on dialysis prescription within the context of a policy of liberal food intake, considering that losses in dialysis should be compensated for by a rich and varied diet, while restrictions may lead to malnutrition instead of improving metabolic parameters.

We are well aware of the limits of our review, which describes an approach to dialysis prescription and the criteria it is based on.

As all concept papers, this working hypothesis awaits validation. We await a longitudinal analysis but until such time as one is undertaken, we would like to have feedback from readers on what they see as the strong and weak points of our hypothesis.

\section{Conclusions and Suggestions for Future Research}

The present concept paper offers a personal interpretation of the current evidence from the pragmatic point of view of dialysis prescription, modeled upon life expectancy and nutritional status.

A longitudinal study is needed to validate this pragmatic approach and to highlight its limits and advantages, in particular in elderly and high-comorbidity dialysis populations.

Author Contributions: Conceptualization, G.B.P. and G.C.; Methodology, G.B.P.; Validation, L.N., L.G. and A.F.; Writing-Original Draft Preparation, G.B.P. and E.C.; Writing-Review \& Editing, G.C.

Funding: This research received no external funding.

Acknowledgments: The authors would like to thank Susan Finnel for her careful language revision.

Conflicts of Interest: The authors declare no conflict of interest.

\section{References}

1. Nistor, I.; Palmer, S.C.; Craig, J.C.; Saglimbene, V.; Vecchio, M.; Covic, A.; Strippoli, G.F. Haemodiafiltration, haemofiltration and haemodialysis for end-stage kidney disease. Cochrane Database Syst. Rev. 2015, CD006258. [CrossRef] [PubMed]

2. Mackenzie, T.A.; Zawada, E.T., Jr.; Stacy, W.K. Hemodialysis. Basic principles and practice. Postgrad. Med. 1985, 77, 95-101 \& 104. [CrossRef] [PubMed]

3. Misra, M. Basic mechanisms governing solute and fluid transport in hemodialysis. Hemodial. Int. 2008, 12 (Suppl. 2), S25-S28. [CrossRef] [PubMed]

4. Hingwala, J.; Tangri, N.; Rigatto, C.; Komenda, P. Improving the quality and efficiency of conventional in-center hemodialysis. Semin. Dial. 2015, 28, 169-175. [CrossRef] [PubMed]

5. Burke, S.K. Phosphate is a uremic toxin. J. Ren. Nutr. 2008, 18, 27-32. [CrossRef] [PubMed]

6. Rodriguez, M.; Lorenzo, V. Parathyroid hormone, a uremic toxin. Semin. Dial. 2009, 22, 363-368. [CrossRef] [PubMed]

7. Vanholder, R.; Van Laecke, S.; Glorieux, G. The middle-molecule hypothesis 30 years after: Lost and rediscovered in the universe of uremic toxicity? J. Nephrol. 2008, 21, 146-160. [PubMed]

8. Vanholder, R.; Baurmeister, U.; Brunet, P.; Cohen, G.; Glorieux, G.; Jankowski, J.; European Uremic Toxin Work Group. A bench to bedside view of uremic toxins. J. Am. Soc. Nephrol. 2008, 19, 863-870. [CrossRef] [PubMed]

9. Glassock, R.J. Uremic toxins: What are they? An integrated overview of pathobiology and classification. J. Ren. Nutr. 2008, 18, 2-6. [CrossRef] [PubMed]

10. Azar, A.T.; Wahba, K.; Mohamed, A.S.; Massoud, W.A. Association between dialysis dose improvement and nutritional status among hemodialysis patients. Am. J. Nephrol. 2007, 27, 113-119. [CrossRef] [PubMed]

11. Combe, C.; Chauveau, P.; Laville, M.; Fouque, D.; Azar, R.; Cano, N.; Canaud, B.; Roth, H.; Leverve, X.; Aparicio, M.; et al. Influence of nutritional factors and hemodialysis adequacy on the survival of 1610 French patients. Am. J. Kidney Dis. 2001, 37 (Suppl. 2), S81-S88. [CrossRef] [PubMed]

12. Yang, C.-S.; Chen, S.-W.; Chiang, C.-H.; Wang, M.; Peng, S.-J.; Kan, Y.-T. Effects of increasing dialysis dose on serum albumin and mortality in hemodialysis patients. Am. J. Kidney Dis. 1996, 27, 380-386. [CrossRef] 
13. Oreopoulos, D.G. Beyond Kt/V: Redefining adequacy of dialysis in the 21st century. Int. Urol. Nephrol. 2002, 34, 393-403. [CrossRef] [PubMed]

14. Wei, M.; Taskapan, H.; Esbaei, K.; Jassal, S.V.; Bargman, J.M.; Oreopoulos, D.G. K/DOQI guideline requirements for calcium, phosphate, calcium phosphate product, and parathyroid hormone control in dialysis patients: Can we achieve them? Int. Urol. Nephrol. 2006, 38, 739-743. [CrossRef] [PubMed]

15. Kimata, N.; Akiba, T.; Pisoni, R.L.; Albert, J.M.; Satayathum, S.; Cruz, J.M.; Akizawa, T.; Andreucci, V.E.; Young, E.W.; Port, F.K. Mineral metabolism and haemoglobin concentration among haemodialysis patients in the Dialysis Outcomes and Practice Patterns Study (DOPPS). Nephrol. Dial. Transplant. 2005, 20, 927-935. [CrossRef] [PubMed]

16. Casino, F.G.; Pedrini, L.A.; Santoro, A.; Mandolfo, S.; David, S.; De Cristofaro, V.; Teatini, U.; Lomonte, C.; Lopez, T. A simple approach for assessing equilibrated Kt/V beta 2-M on a routine basis. Nephrol. Dial. Transplant. 2010, 25, 3038-3044. [CrossRef] [PubMed]

17. Kazama, J.J. Japanese Society of Dialysis Therapy treatment guidelines for secondary hyperparathyroidism. Ther. Apher. Dial. 2007, 11 (Suppl. 1), S44-S47. [CrossRef] [PubMed]

18. Canaud, B.; Barbieri, C.; Marcelli, D.; Bellocchio, F.; Bowry, S.; Mari, F.; Amato, C.; Gatti, E. Optimal convection volume for improving patient outcomes in an international incident dialysis cohort treated with online hemodiafiltration. Kidney Int. 2015, 88, 1108-1116. [CrossRef] [PubMed]

19. Daugirdas, J.T. Hemodialysis Treatment Time: As Important as it Seems? Semin. Dial. 2017, 30, 93-98. [CrossRef] [PubMed]

20. Tattersall, J. Hemodialysis Time and Kt/V: Less May Be Better. Semin. Dial. 2017, 30, 10-14. [CrossRef] [PubMed]

21. Locatelli, F.; Buoncristiani, U.; Canaud, B.; Köhler, H.; Petitclerc, T.; Zucchelli, P. Dialysis dose and frequency. Nephrol. Dial. Transplant. 2005, 20, 285-296. [CrossRef] [PubMed]

22. Raj, D.S.; Charra, B.; Pierratos, A.; Work, J. In search of ideal hemodialysis: Is prolonged frequent dialysis the answer? Am. J. Kidney Dis. 1999, 34, 597-610. [CrossRef]

23. Twardowski, Z.J. We should strive for optimal hemodialysis: A criticism of the hemodialysis adequacy concept. Hemodial. Int. 2003, 7, 5-16. [CrossRef] [PubMed]

24. Gillon, R. Medical ethics: Four principles plus attention to scope. BMJ 1994, 309, 184-188. [CrossRef] [PubMed]

25. Pullman, D. Ethics first aid: Reframing the role of "principlism" in clinical ethics education and practice. J. Clin. Ethics 2005, 16, 223-229. [PubMed]

26. Piccoli, G.B.; Sofronie, A.C.; Coindre, J.P. The strange case of Mr. H. Starting dialysis at 90 years of age: Clinical choices impact on ethical decisions. BMC Med. Ethics 2017, 18, 61. [CrossRef] [PubMed]

27. Cooper, B.A.; Branley, P.; Bulfone, L.; Collins, J.F.; Craig, J.C.; Fraenkel, M.B.; Harris, A.; Johnson, D.W.; Kesselhut, J.; Li, J.J.; et al. A randomized, controlled trial of early versus late initiation of dialysis. N. Engl. J. Med. 2010, 363, 609-619. [CrossRef] [PubMed]

28. Nacak, H.; Bolignano, D.; Van Diepen, M.; Dekker, F.; Van Biesen, W. Timing of start of dialysis in diabetes mellitus patients: A systematic literature review. Nephrol. Dial. Transplant. 2016, 31, 306-316. [CrossRef] [PubMed]

29. Susantitaphong, P.; Altamimi, S.; Ashkar, M.; Balk, E.M.; Stel, V.S.; Wright, S.; Jaber, B.L. GFR at initiation of dialysis and mortality in CKD: A meta-analysis. Am. J. Kidney Dis. 2012, 59, 829-840. [CrossRef] [PubMed]

30. Rivara, M.B.; Mehrotra, R. Timing of Dialysis Initiation: What Has Changed Since IDEAL? Semin. Nephrol. 2017, 37, 181-193. [CrossRef] [PubMed]

31. Clark, W.F.; Na, Y.; Rosansky, S.J.; Sontrop, J.M.; Macnab, J.J.; Glassock, R.J.; Eggers, P.W.; Jackson, K.; Moist, L. Association between estimated glomerular filtration rate at initiation of dialysis and mortality. Can. Med. Assoc. J. 2011, 183, 47-53. [CrossRef] [PubMed]

32. Wongrakpanich, S.; Susantitaphong, P.; Isaranuwatchai, S.; Chenbhanich, J.; Eiam-Ong, S.; Jaber, B.L. Dialysis Therapy and Conservative Management of Advanced Chronic Kidney Disease in the Elderly: A Systematic Review. Nephron 2017. [CrossRef] [PubMed]

33. O'Connor, N.R.; Kumar, P. Conservative management of end-stage renal disease without dialysis: A systematic review. J. Palliat. Med. 2012, 15, 228-235. [CrossRef] [PubMed]

34. Rocha, A.; Sousa, C.; Teles, P.; Coelho, A.; Xavier, E. Frequency of intradialytic hypotensive episodes: Old problem, new insights. J. Am. Soc. Hypertens. 2015, 9, 763-768. [CrossRef] [PubMed] 
35. Agarwal, R. How can we prevent intradialytic hypotension? Curr. Opin. Nephrol. Hypertens. 2012, 21, 593-599. [CrossRef] [PubMed]

36. Twardowski, Z.J. Treatment time and ultrafiltration rate are more important in dialysis prescription than small molecule clearance. Blood Purif. 2007, 25, 90-98. [CrossRef] [PubMed]

37. Golper, T.A. Incremental dialysis: Review of recent literature. Curr. Opin. Nephrol. Hypertens. 2017. epub ahead of print. [CrossRef] [PubMed]

38. Kalantar-Zadeh, K.; Crowley, S.T.; Beddhu, S.; Chen, J.L.; Daugirdas, J.T.; Goldfarb, D.S.; Jin, A.; Kovesdy, C.P.; Leehey, D.J.; Moradi, H.; et al. Renal Replacement Therapy and Incremental Hemodialysis for Veterans with Advanced Chronic Kidney Disease. Semin. Dial. 2017, 30, 251-261. [CrossRef] [PubMed]

39. Yan, Y.; Ramirez, S.; Anand, S.; Qian, J.; Zuo, L. Twice-Weekly Hemodialysis in China: Can It Be A Better Option for Initiation or Maintenance Dialysis Therapy? Semin. Dial. 2017, 30, 277-281. [CrossRef] [PubMed]

40. Basile, C.; Casino, F.G.; Kalantar-Zadeh, K. Is incremental hemodialysis ready to return on the scene? From empiricism to kinetic modelling. J. Nephrol. 2017, 30, 521-529. [CrossRef] [PubMed]

41. Park, J.I.; Park, J.T.; Kim, Y.L.; Kang, S.W.; Yang, C.W.; Kim, N.H.; Oh, Y.K.; Lim, C.S.; Kim, Y.S.; Lee, J.P.; et al. Comparison of outcomes between the incremental and thrice-weekly initiation of hemodialysis: A propensity-matched study of a prospective cohort in Korea. Nephrol. Dial. Transplant. 2017, 32, 355-363. [CrossRef] [PubMed]

42. Bolasco, P.; Cupisti, A.; Locatelli, F.; Caria, S.; Kalantar-Zadeh, K. Dietary Management of Incremental Transition to Dialysis Therapy: Once-Weekly Hemodialysis Combined with Low-Protein Diet. J. Ren. Nutr. 2016, 26, 352-359. [CrossRef] [PubMed]

43. Nesrallah, G.E.; Mustafa, R.A.; Clark, W.F.; Bass, A.; Barnieh, L.; Hemmelgarn, B.R.; Klarenbach, S.; Quinn, R.R.; Hiremath, S.; Ravani, P.; et al. Canadian Society of Nephrology 2014 clinical practice guideline for timing the initiation of chronic dialysis. Can. Med. Assoc. J. 2014, 186, 112-117. [CrossRef] [PubMed]

44. Zha, Y.; Qian, Q. Protein Nutrition and Malnutrition in CKD and ESRD. Nutrients 2017, 9, 208. [CrossRef] [PubMed]

45. Obi, Y.; Qader, H.; Kovesdy, C.P.; Kalantar-Zadeh, K. Latest consensus and update on protein-energy wasting in chronic kidney disease. Curr. Opin. Clin. Nutr. Metab. Care 2015, 18, 254-262. [CrossRef] [PubMed]

46. Carrero, J.J.; Stenvinkel, P.; Cuppari, L.; Ikizler, T.A.; Kalantar-Zadeh, K.; Kaysen, G.; Mitch, W.E.; Price, S.R.; Wanner, C.; Wang, A.Y.; et al. Etiology of the protein-energy wasting syndrome in chronic kidney disease: A consensus statement from the International Society of Renal Nutrition and Metabolism (ISRNM). J. Ren. Nutr. 2013, 23, 77-90. [CrossRef] [PubMed]

47. Kalantar-Zadeh, K.; Kopple, J.D.; Block, G.; Humphreys, M.H. A malnutrition-inflammation score is correlated with morbidity and mortality in maintenance hemodialysis patients. Am. J. Kidney Dis. 2001, 38, 1251-1263. [CrossRef] [PubMed]

48. Hladunewich, M.A.; Hou, S.; Odutayo, A.; Cornelis, T.; Pierratos, A.; Goldstein, M.; Tennankore, K.; Keunen, J.; Hui, D.; Chan, C.T. Intensive hemodialysis associates with improved pregnancy outcomes: A Canadian and United States cohort comparison. J. Am. Soc. Nephrol. 2014, 25, 1103-1109. [CrossRef] [PubMed]

49. Piccoli, G.B.; Minelli, F.; Versino, E.; Cabiddu, G.; Attini, R.; Vigotti, F.N.; Rolfo, A.; Giuffrida, D.; Colombi, N.; Pani, A.; et al. Pregnancy in dialysis patients in the new millennium: A systematic review and meta-regression analysis correlating dialysis schedules and pregnancy outcomes. Nephrol. Dial. Transplant. 2016, 31, 1915-1934. [CrossRef] [PubMed]

50. Tennankore, K.K.; Na, Y.; Wald, R.; Chan, C.T.; Perl, J. Short daily-, nocturnal- and conventional-home hemodialysis have similar patient and treatment survival. Kidney Int. 2018, 93, 188-194. [CrossRef] [PubMed]

51. Pierratos, A. Daily nocturnal hemodialysis-A paradigm shift worthy of disrupting current dialysis practice. Nat. Clin. Pract. Nephrol. 2008, 4, 602-603. [CrossRef] [PubMed]

52. Kjellstrand, C.; Buoncristiani, U.; Ting, G.; Traeger, J.; Piccoli, G.B.; Sibai-Galland, R.; Young, B.A.; Blagg, C.R. Survival with short-daily hemodialysis: Association of time, site, and dose of dialysis. Hemodial. Int. 2010, 14, 464-470. [CrossRef] [PubMed]

53. Piccoli, G.B.; Cabiddu, G.; Moio, M.R.; Fois, A.; Cao, R.; Molfino, I.; Kaniassi, A.; Lippi, F.; Froger, L.; Pani, A.; et al. Efficiency and nutritional parameters in an elderly high risk population on hemodialysis and 
hemodiafiltration in Italy and France: Different treatments with similar names? BMC Nephrol. 2018, 19, 171. [CrossRef] [PubMed]

54. Sum, S.S.; Marcus, A.F.; Blair, D.; Olejnik, L.A.; Cao, J.; Parrott, J.S.; Peters, E.N.; Hand, R.K.; Byham-Gray, L.D. Comparison of Subjective Global Assessment and Protein Energy Wasting Score to Nutrition Evaluations Conducted by Registered Dietitian Nutritionists in Identifying Protein Energy Wasting Risk in Maintenance Hemodialysis Patients. J. Ren. Nutr. 2017, 27, 325-332. [CrossRef] [PubMed]

55. Rodrigues, J.; Cuppari, L.; Campbell, K.L.; Avesani, C.M. Nutritional assessment of elderly patients on dialysis: Pitfalls and potentials for practice. Nephrol. Dial. Transplant. 2017. [CrossRef] [PubMed]

56. Riella, M.C. Nutritional evaluation of patients receiving dialysis for the management of protein-energy wasting: What is old and what is new? J. Ren. Nutr. 2013, 23, 195-198. [CrossRef] [PubMed]

57. van Zuijdewijn, C.L.D.R.; ter Wee, P.M. Assessment of Protein-Energy Wasting: Quest for the Gold Standard. J. Ren. Nutr. 2016, 26, 204-205. [CrossRef] [PubMed]

58. Ikizler, T.A.; Cano, N.J.; Franch, H.; Fouque, D.; Himmelfarb, J.; Kalantar-Zadeh, K.; Kuhlmann, M.K.; Stenvinkel, P.; TerWee, P.; Teta, D.; et al. Prevention and treatment of protein energy wasting in chronic kidney disease patients: A consensus statement by the International Society of Renal Nutrition and Metabolism. Kidney Int. 2013, 84, 1096-1107. [CrossRef] [PubMed]

59. Fried, L.; Bernardini, J.; Piraino, B. Charlson comorbidity index as a predictor of outcomes in incident peritoneal dialysis patients. Am. J. Kidney Dis. 2001, 37, 337-342. [CrossRef] [PubMed]

60. Di Iorio, B.; Cillo, N.; Cirillo, M.; De Santo, N.G. Charlson Comorbidity Index is a predictor of outcomes in incident hemodialysis patients and correlates with phase angle and hospitalization. Int. J. Artif. Organs 2004, 27, 330-336. [CrossRef] [PubMed]

61. Leavey, S.F.; Strawderman, R.L.; Jones, C.A.; Port, F.K.; Held, P.J. Simple nutritional indicators as independent predictors of mortality in hemodialysis patients. Am. J. Kidney Dis. 1998, 31, 997-1006. [CrossRef] [PubMed]

62. Mafra, D.; Farage, N.E.; Azevedo, D.L.; Viana, G.G.; Mattos, J.P.; Velarde, L.G.; Fouque, D. Impact of serum albumin and body-mass index on survival in hemodialysis patients. Int. Urol. Nephrol. 2007, 39, 619-624. [CrossRef] [PubMed]

63. Chertow, G.M.; Johansen, K.L.; Lew, N.; Lazarus, J.M.; Lowrie, E.G. Vintage, nutritional status, and survival in hemodialysis patients. Kidney Int. 2000, 57, 1176-1181. [CrossRef] [PubMed]

64. Tordoir, J.H. Dialysis: Vascular access type defines survival in patients on dialysis. Nat. Rev. Nephrol. 2011, 7, 489-490. [CrossRef] [PubMed]

65. Perl, J.; Wald, R.; McFarlane, P.; Bargman, J.M.; Vonesh, E.; Na, Y.; Jassal, S.V.; Moist, L. Hemodialysis vascular access modifies the association between dialysis modality and survival. J. Am. Soc. Nephrol. 2011, 22, 1113-1121. [CrossRef] [PubMed]

66. Chung, S.H.; Heimbürger, O.; Stenvinkel, P.; Qureshi, A.R.; Lindholm, B. Association between residual renal function, inflammation and patient survival in new peritoneal dialysis patients. Nephrol. Dial. Transplant. 2003, 18, 590-597. [CrossRef] [PubMed]

67. Rhee, H.; Yang, J.Y.; Jung, W.J.; Shin, M.J.; Yang, B.Y.; Song, S.H.; Kwak, I.S.; Seong, E.Y. Significance of residual renal function for phosphate control in chronic hemodialysis patients. Kidney Res. Clin. Pract. 2014, 33, 58-64. [CrossRef] [PubMed]

68. Hecking, M.; Karaboyas, A.; Antlanger, M.; Saran, R.; Wizemann, V.; Chazot, C.; Rayner, H.; Hörl, W.H.; Pisoni, R.L.; Robinson, B.M.; et al. Significance of interdialytic weight gain versus chronic volume overload: Consensus opinion. Am. J. Nephrol. 2013, 38, 78-90. [CrossRef] [PubMed]

69. Kimmel, P.L.; Cohen, S.D.; Weisbord, S.D. Quality of life in patients with end-stage renal disease treated with hemodialysis: Survival is not enough! J. Nephrol. 2008, 21, S54-S58. [PubMed]

70. Sousa-Martins, P.; Moura, A.; Madureira, J.; Alija, P.; Oliveira, J.G.; Lopez, M.; Filgueiras, M.; Amado, L.; Sameiro-Faria, M.; Miranda, V.; et al. Risk factors for mortality in end-stage kidney disease patients under online-hemodiafiltration: Three-year follow-up study. Biomarkers 2016, 21, 544-550. [CrossRef] [PubMed]

71. Imamović, G.; Hrvačević, R.; Kapun, S.; Marcelli, D.; Bayh, I.; Grassmann, A.; Scatizzi, L.; Maslovarić, J.; Canaud, B. Survival of incident patients on high-volume online hemodiafiltration compared to low-volume online hemodiafiltration and high-flux hemodialysis. Int. Urol. Nephrol. 2014, 46, 1191-2001. [CrossRef] [PubMed] 
72. Vega, A.; Quiroga, B.; Abad, S.; Aragoncillo, I.; Arroyo, D.; Panizo, N.; López-Gómez, J.M. Albumin leakage in online hemodiafiltration, more convective transport, more losses? Ther. Apher. Dial. 2015, 19, $267-271$. [CrossRef] [PubMed]

73. Florens, N.; Juillard, L. Large Middle Molecule and Albumin Removal: Why Should We Not Rest on Our Laurels? Contrib. Nephrol. 2017, 191, 178-187. [PubMed]

74. Krieter, D.H.; Canaud, B. High permeability of dialysis membranes: What is the limit of albumin loss. Nephrol. Dial. Transplant. 2003, 18, 651-654. [CrossRef] [PubMed]

75. Nagai, K.; Tsuchida, K.; Hirose, D.; Michiwaki, H.; Hann, M.; Kanayama, H.O.; Doi, T.; Minakuchi, J. The effect of albumin leakage in hemodialysis patients on redox status of serum albumin. J. Artif. Organs 2016, 19, 310-314. [CrossRef] [PubMed]

76. Nagai, K.; Tsuchida, K.; Ishihara, N.; Minagawa, N.; Ichien, G.; Yamada, S.; Hirose, D.; Michiwaki, H.; Kanayama, H.O.; Doi, T.; et al. Implications of Albumin Leakage for Survival in Maintenance Hemodialysis Patients: A 7-year Observational Study. Ther. Apher. Dial. 2017, 21, 378-386. [CrossRef] [PubMed]

77. Tsuchida, K.; Minakuchi, J. Albumin loss under the use of the high-performance membrane. Contrib. Nephrol. 2011, 173, 76-83. [PubMed]

78. Santoro, A.; Guadagni, G. Dialysis membrane: From convection to adsorption. NDT Plus 2010, 3 (Suppl. 1), i36-i39. [CrossRef] [PubMed]

79. Urbani, A.; Sirolli, V.; Lupisella, S.; Levi-Mortera, S.; Pavone, B.; Pieroni, L.; Amoroso, L.; Di Vito, R.; Bucci, S.; Bernardini, S.; et al. Proteomic investigations on the effect of different membrane materials on blood protein adsorption during haemodialysis. Blood Transfus. 2012, 10 (Suppl. 2), S101-S112. [PubMed]

80. Marcason, W. Should Albumin and Prealbumin Be Used as Indicators for Malnutrition? J. Acad. Nutr. Diet. 2017, 117, 1144. [CrossRef] [PubMed]

81. Santin, F.; Rodrigues, J.; Brito, F.B.; Avesani, C.M. Performance of subjective global assessment and malnutrition inflammation score for monitoring the nutritional status of older adults on hemodialysis. Clin. Nutr. 2018, 37, 604-611. [CrossRef] [PubMed]

82. Lopes, M.B.; Silva, L.F.; Lopes, G.B.; Penalva, M.A.; Matos, C.M.; Robinson, B.M.; Lopes, A.A. Additional Contribution of the Malnutrition-Inflammation Score to Predict Mortality and Patient-Reported Outcomes as Compared With Its Components in a Cohort of African Descent Hemodialysis Patients. J. Ren. Nutr. 2017, 27, 45-52. [CrossRef] [PubMed]

83. Kalantar-Zadeh, K.; Kopple, J.D.; Humphreys, M.H.; Block, G. Comparing outcome predictability of markers of malnutrition-inflammation complex syndrome in haemodialysis patients. Nephrol. Dial. Transplant. 2004, 19, 1507-1519. [CrossRef] [PubMed]

84. Jones, C.H.; Wolfenden, R.C.; Wells, L.M. Is subjective global assessment a reliable measure of nutritional status in hemodialysis? J. Ren. Nutr. 2004, 14, 26-30. [CrossRef] [PubMed]

85. Gurreebun, F.; Hartley, G.H.; Brown, A.L.; Ward, M.C.; Goodship, T.H. Nutritional screening in patients on hemodialysis: Is subjective global assessment an appropriate tool? J. Ren. Nutr. 2007, 17, 114-117. [CrossRef] [PubMed]

86. Eriguchi, R.; Obi, Y.; Streja, E.; Tortorici, A.R.; Rhee, C.M.; Soohoo, M.; Kim, T.; Kovesdy, C.P.; Kalantar-Zadeh, K. Longitudinal Associations among Renal Urea Clearance-Corrected Normalized Protein Catabolic Rate, Serum Albumin, and Mortality in Patients on Hemodialysis. Clin. J. Am. Soc. Nephrol. 2017, 12, 1109-1117. [CrossRef] [PubMed]

87. Sreedhara, R.; Avram, M.M.; Blanco, M.; Batish, R.; Avram, M.M.; Mittman, N. Prealbumin is the best nutritional predictor of survival in hemodialysis and peritoneal dialysis. Am. J. Kidney Dis. 1996, 28, 937-942. [CrossRef]

88. Takahashi, R.; Ito, Y.; Takahashi, H.; Ishii, H.; Kasuga, H.; Mizuno, M.; Suzuki, Y.; Yuzawa, Y.; Maruyama, S.; Murohara, T.; et al. Combined values of serum albumin, C-reactive protein and body mass index at dialysis initiation accurately predicts long-term mortality. Am. J. Nephrol. 2012, 36, 136-143. [CrossRef] [PubMed]

89. Kovesdy, C.P.; Kalantar-Zadeh, K. Accuracy and limitations of the diagnosis of malnutrition in dialysis patients. Semin. Dial. 2012, 25, 423-427. [CrossRef] [PubMed]

90. Takahashi, H.; Inoue, K.; Shimizu, K.; Hiraga, K.; Takahashi, E.; Otaki, K.; Yoshikawa, T.; Furuta, K.; Tokunaga, C.; Sakakibara, T.; et al. Comparison of Nutritional Risk Scores for Predicting Mortality in Japanese Chronic Hemodialysis Patients. J. Ren. Nutr. 2017, 27, 201-206. [CrossRef] [PubMed] 
91. De Roij van Zuijdewijn, C.L.; ter Wee, P.M.; Chapdelaine, I.; Bots, M.L.; Blankestijn, P.J.; van den Dorpel, M.A.; Nubé, M.J.; Grooteman, M.P. A Comparison of 8 Nutrition-Related Tests to Predict Mortality in Hemodialysis Patients. J. Ren. Nutr. 2015, 25, 412-419. [CrossRef] [PubMed]

92. Hoshino, J.; Yamagata, K.; Nishi, S.; Nakai, S.; Masakane, I.; Iseki, K.; Tsubakihara, Y. Significance of the decreased risk of dialysis-related amyloidosis now proven by results from Japanese nationwide surveys in 1998 and 2010. Nephrol. Dial. Transplant. 2016, 31, 595-602. [CrossRef] [PubMed]

93. Tsuchida, K.; Minakuchi, J. Effect of large-size dialysis membrane and hemofiltration/hemodiafiltration methods on long-term dialysis patients. Contrib. Nephrol. 2011, 168, 179-187. [PubMed]

94. Fujimori, A. Beta-2-microglobulin as a uremic toxin: The Japanese experience. Contrib. Nephrol. 2011, 168, 129-133. [PubMed]

95. Thomas, G.; Jaber, B.L. Convective therapies for removal of middle molecular weight uremic toxins in end-stage renal disease: A review of the evidence. Semin. Dial. 2009, 22, 610-614. [CrossRef] [PubMed]

96. Drüeke, T.B.; Massy, Z.A. Beta2-microglobulin. Semin. Dial. 2009, 22, 378-380. [CrossRef] [PubMed]

97. Canaud, B.; Koehler, K.; Bowry, S.; Stuard, S. What Is the Optimal Target Convective Volume in On-Line Hemodiafiltration Therapy? Electrolyte Blood Press 2016, 14, 1-4.

98. Canaud, B. Online hemodiafiltration. Technical options and best clinical practices. Contrib. Nephrol. 2007, 158, 110-122. [PubMed]

99. Ahrenholz, P.G.; Winkler, R.E.; Michelsen, A.; Lang, D.A.; Bowry, S.K. Dialysis membrane-dependent removal of middle molecules during hemodiafiltration: The beta2-microglobulin/albumin relationship. Clin. Nephrol. 2004, 62, 21-28. [CrossRef] [PubMed]

100. Schiffl, H. High-flux dialyzers, backfiltration, and dialysis fluid quality. Semin. Dial. 2011, 24, 1-4. [CrossRef] [PubMed]

101. Schiffl, H. Prospective randomized cross-over long-term comparison of online haemodiafiltration and ultrapure high-flux haemodialysis. Eur. J. Med. Res. 2007, 12, 26-33. [PubMed]

102. Van Biesen, W.; Vanholder, R.; Schepers, E.; Glorieux, G.; Dhondt, A.; Eloot, S. The Place of Large Pore Membranes in the Treatment Portfolio of Patients on Hemodialysis. Contrib. Nephrol. 2017, 191, 168-177. [PubMed]

103. Macías, N.; Vega, A.; Abad, S.; Santos, A.; Cedeño, S.; Linares, T.; García-Prieto, A.M.; Aragoncillo, I.; Yuste, C.; López-Gómez, J.M. Is High-Volume Online Hemodiafiltration Associated with Malnutrition? Ther. Apher. Dial. 2017, 21, 361-369. [CrossRef] [PubMed]

104. Weng, C.H.; Hsu, C.W.; Hu, C.C.; Yen, T.H.; Huang, W.H. Association Between Hemodiafiltration and Hypoalbuminemia in Middle-Age Hemodialysis Patients. Medicine 2016, 95, e3334. [CrossRef] [PubMed]

105. Zhang, Z.H.; Mao, J.R.; Chen, H.; Su, W.; Zhang, Y.; Zhang, L.; Chen, D.Q.; Zhao, Y.Y.; Vaziri, N.D. Removal of uremic retention products by hemodialysis is coupled with indiscriminate loss of vital metabolites. Clin. Biochem. 2017, 50, 1078-1086. [CrossRef] [PubMed]

106. Jankowska, M.; Cobo, G.; Lindholm, B.; Stenvinkel, P. Inflammation and Protein-Energy Wasting in the Uremic Milieu. Contrib. Nephrol. 2017, 191, 58-71. [PubMed]

107. Piccoli, G.B.; Moio, M.R.; Fois, A.; Sofronie, A.; Gendrot, L.; Cabiddu, G.; D'Alessandro, C.; Cupisti, A. The Diet and Haemodialysis Dyad: Three Eras, Four Open Questions and Four Paradoxes. A Narrative Review, Towards a Personalized, Patient-Centered Approach. Nutrients 2017, 9, 372. [CrossRef] [PubMed]

108. Tsuchida, K.; Minakuchi, J. Clinical benefits of predilution on-line hemodiafiltration. Contrib. Nephrol. 2007, 158, 110-122. [CrossRef] [PubMed]

109. Kim, Y.W.; Park, S. Confronting Practical Problems for Initiation of On-line Hemodiafiltration Therapy. Blood Purif. 2013, 35 (Suppl. 1), 18-22. [CrossRef] [PubMed]

110. Morfin, J.A.; Fluck, R.J.; Weinhandl, E.D.; Kansal, S.; McCullough, P.A.; Komenda, P. Intensive Hemodialysis and Treatment Complications and Tolerability. Am. J. Kidney Dis. 2016, 68, S43-S50. [CrossRef] [PubMed]

111. Zhao, Y.; Pei, X.; Zhao, W. Timing of Dialysis Initiation and Mortality Risk in Chronic Kidney Disease: A Meta-Analysis. Ther. Apher. Dial. 2018. [CrossRef] [PubMed]

112. A "New Normal": Life on Dialysis—The First 90 Days. Available online: https://www.kidney.org/sites/ default/files/docs/11-10-0307_dialysistransitionbk2_oct07_lr_bm.pdf (accessed on 6 August 2018).

113. Machowska, A.; Alscher, M.D.; Vanga, S.R.; Koch, M.; Aarup, M.; Qureshi, A.R.; Lindholm, B.; Rutherford, P. Offering Patients Therapy Options in Unplanned Start (OPTiONS): Implementation of an educational program is feasible and effective. BMC Nephrol. 2017, 18, 18. [CrossRef] [PubMed] 
114. Matsuzawa, R.; Roshanravan, B. Management of Physical Frailty in Patients Requiring Hemodialysis Therapy. Contrib. Nephrol. 2018, 196, 101-109. [PubMed]

115. Johansen, K.L. The Frail Dialysis Population: A Growing Burden for the Dialysis Community. Blood Purif. 2015, 40, 288-292. [CrossRef] [PubMed]

116. Jaber, B.L.; Lee, Y.; Collins, A.J.; Hull, A.R.; Kraus, M.A.; McCarthy, J.; Miller, B.W.; Spry, L.; Finkelstein, F.O.; FREEDOM Study Group. Effect of daily hemodialysis on depressive symptoms and postdialysis recovery time: Interim report from the FREEDOM (Following Rehabilitation, Economics and Everyday-Dialysis Outcome Measurements) Study. Am. J. Kidney Dis. 2010, 56, 531-539. [CrossRef] [PubMed]

117. Piccoli, G.B.; Bechis, F.; Pozzato, M.; Ettari, G.; Alloatti, S.; Vischi, M.; Mezza, E.; Iacuzzo, C.; Quaglia, M.; Burdese, M.; et al. Daily Dialysis: Toward a New Standard in Well-Being. Hemodial. Int. 2001, 5, 19-27. [CrossRef] [PubMed]

118. Canaud, B.; Lévesque, R.; Krieter, D.; Desmeules, S.; Chalabi, L.; Moragués, H.; Morena, M.; Cristol, J.P. On-line hemodiafiltration as routine treatment of end-stage renal failure: Why pre- or mixed dilution mode is necessary in on-line hemodiafiltration today? Blood Purif. 2004, 22 (Suppl. 2), 40-48. [CrossRef] [PubMed]

119. Blankestijn, P.J.; Davenport, A.; Basile, C.; Locatelli, F.; Maduell, F.; Mitra, S.; Ronco, C.; Shroff, R.; Tattersall, J.; Wanner, C. Optimization of the convection volume in online post-dilution haemodiafiltration: Practical and technical issues. Clin. Kidney J. 2015, 8, 191-198.

120. Ikizler, T.A. A patient with CKD and poor nutritional status. Clin. J. Am. Soc. Nephrol. 2013, 8, $2174-2182$. [CrossRef] [PubMed]

121. Panichi, V.; Rocchetti, M.T.; Scatena, A.; Rosati, A.; Migliori, M.; Pizzarelli, F.; Gesualdo, L.; REDERT Study Group. Long term variation of serum levels of uremic toxins in patients treated by post-dilution high volume on-line hemodiafiltration in comparison to standard low-flux bicarbonate dialysis: Results from the REDERT study. J. Nephrol. 2017, 30, 583-591. [CrossRef] [PubMed]

122. Potier, J.; Le Roy, F.; Faucon, J.P.; Besselièvre, T.; Renaudineau, E.; Farquet, C.; Soihan, P.; Touzard, D.; Djema, A.; Ilinca, T. Elevated removal of middle molecules without significant albumin loss with mixed-dilution hemodiafiltration for patients unable to provide sufficient blood flow rates. Blood Purif. 2013, 36, 78-83. [CrossRef] [PubMed]

123. Casino, F.G.; Basile, C. How to set the stage for a full-fledged clinical trial testing 'incremental haemodialysis'. Nephrol. Dial. Transplant. 2017. [CrossRef] [PubMed]

124. Mathew, A.T.; Fishbane, S.; Obi, Y.; Kalantar-Zadeh, K. Preservation of residual kidney function in hemodialysis patients: Reviving an old concept. Kidney Int. 2016, 90, 262-271. [CrossRef] [PubMed]

125. Toth-Manikowski, S.M.; Mullangi, S.; Hwang, S.; Shafi, T. Incremental short daily home hemodialysis: A case series. BMC Nephrol. 2017, 18, 216. [CrossRef] [PubMed]

126. Shafi, T.; Mullangi, S.; Toth-Manikowski, S.M.; Hwang, S.; Michels, W.M. Residual Kidney Function: Implications in the Era of Personalized Medicine. Semin. Dial. 2017, 30, 241-245. [CrossRef] [PubMed]

127. Liu, X.; Dai, C. Advances in Understanding and Management of Residual Renal Function in Patients with Chronic Kidney Disease. Kidney Dis. 2017, 2, 187-196. [CrossRef] [PubMed]

128. Lowenstein, J.; Grantham, J.J. Residual renal function: A paradigm shift. Kidney Int. 2017, 91, 561-565. [CrossRef] [PubMed]

129. Shafi, T.; Jaar, B.G.; Plantinga, L.C.; Fink, N.E.; Sadler, J.H.; Parekh, R.S.; Powe, N.R.; Coresh, J. Association of residual urine output with mortality, quality of life, and inflammation in incident hemodialysis patients: The Choices for Healthy Outcomes in Caring for End-Stage Renal Disease (CHOICE) Study. Am. J. Kidney Dis. 2010, 56, 348-358. [CrossRef] [PubMed]

130. Belmouaz, M.; Diolez, J.; Bauwens, M.; Duthe, F.; Ecotiere, L.; Desport, E.; Bridoux, F. Comparison of hemodialysis with medium cut-off dialyzer and on-line hemodiafiltration on the removal of small and middle-sized molecules. Clin. Nephrol. 2017. [CrossRef] [PubMed]

131. Kalantar-Zadeh, K.; Block, G.; Humphreys, M.H.; Kopple, J.D. Reverse epidemiology of cardiovascular risk factors in maintenance dialysis patients. Kidney Int. 2003, 63, 793-808. [CrossRef] [PubMed]

132. Kalantar-Zadeh, K.; Kopple, J.D. Obesity paradox in patients on maintenance dialysis. Contrib. Nephrol. 2006, 151,57-69. [PubMed]

133. Rangel, A.V.; Kim, J.C.; Kaushik, M.; Garzotto, F.; Neri, M.; Cruz, D.N.; Ronco, C. Backfiltration: Past, present and future. Contrib. Nephrol. 2011, 175, 35-45. [PubMed] 
134. Kirsch, A.H.; Lyko, R.; Nilsson, L.G.; Beck, W.; Amdahl, M.; Lechner, P.; Schneider, A.; Wanner, C.; Rosenkranz, A.R.; Krieter, D.H. Performance of hemodialysis with novel medium cut-off dialyzers. Nephrol. Dial. Transplant. 2017, 32, 165-172. [CrossRef] [PubMed]

135. Lorenzin, A.; Neri, M.; Clark, W.R.; Garzotto, F.; Brendolan, A.; Nalesso, F.; Marchionna, N.; Zanella, M.; Sartori, M.; Fiore, G.B.; et al. Modeling of Internal Filtration in Theranova Hemodialyzers. Contrib. Nephrol. 2017, 191, 127-141. [PubMed]

136. Calabia, J.; Arcos, E.; Carrero, J.J.; Comas, J.; Vallés, M. Does the obesity survival paradox of dialysis patients differ with age? Blood Purif. 2015, 39, 193-199. [CrossRef] [PubMed]

137. Vashistha, T.; Mehrotra, R.; Park, J.; Streja, E.; Dukkipati, R.; Nissenson, A.R.; Ma, J.Z.; Kovesdy, C.P.; Kalantar-Zadeh, K. Effect of age and dialysis vintage on obesity paradox in long-term hemodialysis patients. Am. J. Kidney Dis. 2014, 63, 612-622. [CrossRef] [PubMed]

138. Androga, L.; Sharma, D.; Amodu, A.; Abramowitz, M.K. Sarcopenia, obesity, and mortality in US adults with and without chronic kidney disease. Kidney Int. Rep. 2017, 2, 201-211. [CrossRef] [PubMed]

139. Kittiskulnam, P.; Carrero, J.J.; Chertow, G.M.; Kaysen, G.A.; Delgado, C.; Johansen, K.L. Sarcopenia among patients receiving hemodialysis: Weighing the evidence. J. Cachexia Sarcopenia Muscle 2017, 8, 57-68. [CrossRef] [PubMed]

140. Piccoli, A.; Brunani, A.; Savia, G.; Pillon, L.; Favaro, E.; Berselli, M.E.; Cavagnini, F. Discriminating between body fat and fluid changes in the obese adult using bioimpedance vector analysis. Int. J. Obes. Relat. Metab. Disord. 1998, 22, 97-104. [CrossRef] [PubMed]

141. Guida, B.; De Nicola, L.; Pecoraro, P.; Trio, R.; Di Paola, F.; Iodice, C.; Bellizzi, V.; Memoli, B. Abnormalities of bioimpedance measures in overweight and obese hemodialyzed patients. Int. J. Obes. Relat. Metab. Disord. 2001, 25, 265-272. [CrossRef] [PubMed]

142. Torun, D.; Micozkadioglu, H.; Torun, N.; Ozelsancak, R.; Sezer, S.; Adam, F.U.; Ozdemir, F.N.; Haberal, M. Increased body mass index is not a reliable marker of good nutrition in hemodialysis patients. Ren. Fail. 2007, 29, 487-493. [CrossRef] [PubMed]

143. Salahudeen, A.K.; Fleischmann, E.H.; Bower, J.D. Impact of lower delivered Kt/V on the survival of overweight patients on hemodialysis. Kidney Int. 1999, 56, 2254-2259. [CrossRef] [PubMed]

144. Davenport, A. Differences in prescribed Kt/V and delivered haemodialysis dose-Why obesity makes a difference to survival for haemodialysis patients when using a 'one size fits all' $\mathrm{Kt} / \mathrm{V}$ target. Nephrol. Dial. Transplant. 2013, 28 (Suppl. 4), iv219-iv223. [CrossRef] [PubMed]

145. Segall, L.; Moscalu, M.; Hogaş, S.; Mititiuc, I.; Nistor, I.; Veisa, G.; Covic, A. Protein-energy wasting, as well as overweight and obesity, is a long-term risk factor for mortality in chronic hemodialysis patients. Int. Urol. Nephrol. 2014, 46, 615-621. [CrossRef] [PubMed]

146. Ikizler, T.A. Using and interpreting serum albumin and prealbumin as nutritional markers in patients on chronic dialysis. Semin. Dial. 2014, 27, 590-592. [CrossRef] [PubMed]

147. Desai, A.A.; Nissenson, A.; Chertow, G.M.; Farid, M.; Singh, I.; Van Oijen, M.G.; Esrailian, E.; Solomon, M.D.; Spiegel, B.M. The relationship between laboratory-based outcome measures and mortality in end-stage renal disease: A systematic review. Hemodial. Int. 2009, 13, 347-359. [CrossRef] [PubMed]

148. Herselman, M.; Esau, N.; Kruger, J.M.; Labadarios, D.; Moosa, M.R. Relationship between serum protein and mortality in adults on long-term hemodialysis: Exhaustive review and meta-analysis. Nutrition 2010, 26, 10-32. [CrossRef] [PubMed]

149. Beberashvili, I.; Sinuani, I.; Azar, A.; Shapiro, G.; Feldman, L.; Stav, K.; Sandbank, J.; Averbukh, Z. Serum uric acid as a clinically useful nutritional marker and predictor of outcome in maintenance hemodialysis patients. Nutrition 2015, 31, 138-147. [CrossRef] [PubMed]

150. Park, C.; Obi, Y.; Streja, E.; Rhee, C.M.; Catabay, C.J.; Vaziri, N.D.; Kovesdy, C.P.; Kalantar-Zadeh, K. Serum uric acid, protein intake and mortality in hemodialysis patients. Nephrol. Dial. Transplant. 2017, 32, 1750-1757. [CrossRef] [PubMed]

151. Lines, S.W.; Richardson, V.R.; Thomas, B.; Dunn, E.J.; Wright, M.J.; Carter, A.M. Complement and cardiovascular disease-The missing link in haemodialysis patients? Nephron 2016, 132, 5-14. [CrossRef] [PubMed]

152. Marçais, C.; Maucort-Boulch, D.; Drai, J.; Dantony, E.; Carlier, M.C.; Blond, E.; Genet, L.; Kuentz, F.; Lataillade, D.; Legrand, E.; et al. Circulating Klotho Associates with Cardiovascular Morbidity and Mortality During Hemodialysis. J. Clin. Endocrinol. Metab. 2017, 102, 3154-3161. [CrossRef] [PubMed] 
153. Cianciolo, G.; Galassi, A.; Capelli, I.; Schillaci, R.; La Manna, G.; Cozzolino, M. Klotho-FGF23, Cardiovascular Disease, and Vascular Calcification: Black or White? Curr. Vasc. Pharmacol. 2018, 16, 143-156. [CrossRef] [PubMed]

154. Artunc, F.; Nowak, A.; Müller, C.; Peter, A.; Heyne, N.; Häring, H.U.; Friedrich, B. Mortality prediction using modern peptide biomarkers in hemodialysis patients-A comparative analysis. Kidney Blood Press Res. 2014, 39, 563-572. [CrossRef] [PubMed]

155. Marthi, A.; Donovan, K.; Haynes, R.; Wheeler, D.C.; Baigent, C.; Rooney, C.M.; Landray, M.J.; Moe, S.M.; Yang, J.; Holland, L.; et al. Fibroblast Growth Factor-23 and Risks of Cardiovascular and Noncardiovascular Diseases: A Meta-Analysis. J. Am. Soc. Nephrol. 2018, 29, 2015-2027. [CrossRef] [PubMed]

156. Krzanowski, M.; Krzanowska, K.; Dumnicka, P.; Gajda, M.; Woziwodzka, K.; Fedak, D.; Grodzicki, T.; Litwin, J.A.; Sułowicz, W. Elevated Circulating Osteoprotegerin Levels in the Plasma of Hemodialyzed Patients with Severe Artery Calcifications. Ther. Apher. Dial. 2018. [CrossRef] [PubMed]

157. Scialla, J.J.; Kao, W.H.; Crainiceanu, C.; Sozio, S.M.; Oberai, P.C.; Shafi, T.; Coresh, J.; Powe, N.R.; Plantinga, L.C.; Jaar, B.G.; et al. Biomarkers of vascular calcification and mortality in patients with ESRD. Clin. J. Am. Soc. Nephrol. 2014, 9, 745-755. [CrossRef] [PubMed]

158. Kashiwagi, T.; Sato, K.; Kawakami, S.; Kiyomoto, M.; Enomoto, M.; Suzuki, T.; Genei, H.; Nakada, H.; Iino, Y.; Katayama, Y. Effects of reduced dialysis fluid flow in hemodialysis. J. Nippon Med. Sch. 2013, 80, 119-130. [CrossRef] [PubMed]

159. Ponce, P.; Marcelli, D.; Scholz, C.; Wehmeyer, W.; Gonçalves, P.; Grassmann, A.; Brand, K.; Canaud, B. Does the extracorporeal blood flow affect survival of the arteriovenous vascular access? Hemodial. Int. 2015, 19, 314-322. [CrossRef] [PubMed]

160. Mandolfo, S.; Borlandelli, S.; Imbasciati, E.; Badalamenti, S.; Graziani, G.; Sereni, L.; Varesani, M.; Wratten, M.L.; Corsi, A.; Elli, A. Pilot study to assess increased dialysis efficiency in patients with limited blood flow rates due to vascular access problems. Hemodial. Int. 2008, 12, 55-61. [CrossRef] [PubMed]

161. Mandolfo, S.; Borlandelli, S.; Ravani, P.; Imbasciati, E. How to improve dialysis adequacy in patients with vascular access problems. J. Vasc. Access. 2006, 7, 53-59. [CrossRef] [PubMed]

162. Cortez, A.J.; Paulson, W.D.; Schwab, S.J. Vascular access as a determinant of adequacy of dialysis. Semin. Nephrol. 2005, 25, 96-101. [CrossRef] [PubMed]

163. Lee, T.; Thamer, M.; Zhang, Q.; Zhang, Y.; Allon, M. Vascular Access Type and Clinical Outcomes among Elderly Patients on Hemodialysis. Clin. J. Am. Soc. Nephrol. 2017, 12, 1823. [CrossRef] [PubMed]

164. Gill, S.; Quinn, R.; Oliver, M.; Kamar, F.; Kabani, R.; Devoe, D.; Mysore, P.; Pannu, N.; MacRae, J.; Manns, B.; et al. Multi-Disciplinary Vascular Access Care and Access Outcomes in People Starting Hemodialysis Therapy. Clin. J. Am. Soc. Nephrol. 2017, 12, 1991-1999. [CrossRef] [PubMed]

165. Lee, T.; Allon, M. Reassessing Recommendations for Choice of Vascular Access. Clin. J. Am. Soc. Nephrol. 2017, 12, 865-867. [CrossRef] [PubMed]

166. Hall, R.K.; Myers, E.R.; Rosas, S.E.; O’Hare, A.M.; Colón-Emeric, C.S. Choice of Hemodialysis Access in Older Adults: A Cost-Effectiveness Analysis. Clin. J. Am. Soc. Nephrol. 2017, 12, 947-954. [CrossRef] [PubMed]

167. Hod, T.; Goldfarb-Rumyantzev, A.S.; Patibandla, B.K.; Narra, A.; Brown, R.S. Second vascular access after failure of the first fistula in the elderly. Clin. Nephrol. 2016, 86, 253-261. [CrossRef] [PubMed]

168. Kawanishi, H.; Shintaku, S.; Moriishi, M. Vascular access in super-aged patients. J. Vasc. Access. 2015, 16 (Suppl. 10), S22-S27. [CrossRef] [PubMed]

169. Kessler, M.; Moureau, F.; Nguyen, P. Anticoagulation in Chronic Hemodialysis: Progress Toward an Optimal Approach. Semin. Dial. 2015, 28, 474-489. [PubMed]

170. Harel, Z.; Chertow, G.M.; Shah, P.S.; Harel, S.; Dorian, P.; Yan, A.T.; Saposnik, G.; Sood, M.M.; Molnar, A.O.; Perl, J.; et al. Warfarin and the Risk of Stroke and Bleeding in Patients with Atrial Fibrillation Receiving Dialysis: A Systematic Review and Meta-analysis. Can. J. Cardiol. 2017, 33, 737-746. [CrossRef] [PubMed]

171. Lin, M.C.; Streja, E.; Soohoo, M.; Hanna, M.; Savoj, J.; Kalantar-Zadeh, K.; Lau, W.L. Warfarin Use and Increased Mortality in End-Stage Renal Disease. Am. J. Nephrol. 2017, 46, 249-256. [CrossRef] [PubMed]

172. Islam, M.S.; Hassan, Z.A.; Chalmin, F.; Vido, S.; Berrada, M.; Verhelst, D.; Donnadieu, P.; Moranne, O.; Esnault, V.L. Vitamin E-Coated and Heparin-Coated Dialyzer Membranes for Heparin-Free Hemodialysis: A Multicenter, Randomized, Crossover Trial. Am. J. Kidney Dis. 2016, 68, 752-762. [CrossRef] [PubMed] 
173. Meijers, B.K.; Poesen, R.; Evenepoel, P. Heparin-coated dialyzer membranes: Is non-inferiority good enough? Kidney Int. 2014, 86, 1084-1086. [CrossRef] [PubMed]

174. Hu, S.L.; Joshi, P.; Kaplan, M.; Lefkovitz, J.; Poenariu, A.; Dworkin, L.D.; Michaud, D.S. Rapid Change in Renal Function Decline Is Associated with Lower Survival and Worse Residual Renal Function Preservation in Peritoneal Dialysis Patients. Perit. Dial. Int. 2017, 37, 477-481. [CrossRef] [PubMed]

175. Schiffl, H.; Lang, S.M.; Fischer, R. Effects of high efficiency post-dilution on-line hemodiafiltration or conventional hemodialysis on residual renal function and left ventricular hypertrophy. Int. Urol. Nephrol. 2013, 45, 1389-1396. [CrossRef] [PubMed]

176. Hyodo, T.; Koutoku, N. Preservation of residual renal function with HDF. Contrib. Nephrol. 2011, 168, $204-212$. [PubMed]

177. Davenport, A. Measuring residual renal function for hemodialysis adequacy: Is there an easier option? Hemodial. Int. 2017, 21 (Suppl. 2), S41-S46. [CrossRef] [PubMed]

178. Swaminathan, S.; Mor, V.; Mehrotra, R.; Trivedi, A.N. Initial Session Duration and Mortality Among Incident Hemodialysis Patients. Am. J. Kidney Dis. 2017, 70, 69-75. [CrossRef] [PubMed]

179. Kitagawa, M.; Sada, K.E.; Hinamoto, N.; Kimachi, M.; Yamamoto, Y.; Onishi, Y.; Fukuhara, S. Shorter dialysis session length was not associated with lower mental health and physical functioning in elderly hemodialysis patients: Results from the Japan Dialysis Outcome and Practice Patterns Study (J-DOPPS). PLoS ONE 2017, 12, e0184019. [CrossRef] [PubMed]

180. Mourad, G.; Minguet, J.; Pernin, V.; Garrigue, V.; Peraldi, M.N.; Kessler, M.; Jacquelinet, C.; Couchoud, C.; Duny, Y.; Daurès, J.P. Similar patient survival following kidney allograft failure compared with non-transplanted patients. Kidney Int. 2014, 86, 191-198. [CrossRef] [PubMed]

181. Brar, A.; Markell, M.; Stefanov, D.G.; Timpo, E.; Jindal, R.M.; Nee, R.; Sumrani, N.; John, D.; Tedla, F.; Salifu, M.O. Mortality after Renal Allograft Failure and Return to Dialysis. Am. J. Nephrol. 2017, 45, 180-186. [CrossRef] [PubMed]

182. Molnar, M.Z.; Ichii, H.; Lineen, J.; Foster, C.E., 3rd; Mathe, Z.; Schiff, J.; Kim, S.J.; Pahl, M.V.; Amin, A.N.; Kalantar-Zadeh, K.; et al. Timing of return to dialysis in patients with failing kidney transplants. Semin. Dial. 2013, 26, 667-674. [CrossRef] [PubMed] 